\title{
THE IMPACT OF ORGANIC AND MINERAL FERTILIZATIONS, PLANT SPACING AND FOLIAR APLICATON OF YEAST AND GARLIC EXTRACT ON SEED PRODUCTION OF SQUASH. \\ 1-VEGETATIVE GROWTH CONSTITUENTS \\ Tartoura, E A. A¹.; E. E. El-Gamily'1.; Y.B.A. El-Waraky² and A.A.M. Fayed $^{2}$ \\ 1-Veg. and Flori. Dept. Fac. Agric., Mansoura. Univ., Egypt. \\ 2-Hort. Inst., ARC, Egypt
}

\begin{abstract}
This study was carried out during the two summer seasons of 2011 and 2012 at Sakha Agricultural Research Station Farm, Kafr El-Sheikh Governorate, Egypt on summer squash (Cucurbita pepo L.) El-Askandarani cultivar to study the impact of plant spacing $(30,40$ and $60 \mathrm{~cm}$ between plants), nitrogen fertilizer sources (organic and inorganic) and foliar spray with biostmulants(garlic or yeast extracts) and their interactions on vegetative parameters and leaf chemical constituents. Resultes indicated that, the highest values of vegetative growth characters i.e., plant length, number of leaves, fresh and dry weight, leaf area and chlorophyll contents in leaves as well as chemical constituents of leaves(N, P, K, Fe, Zn and Mn)were recorded when plants growing at $60 \mathrm{~cm}$ between plants. Squash plants sprayed with $2.5 \mathrm{~cm} \backslash$ garlic extracts recorded better growth performance and higher values of chemical constituents of leaves than unsprayed plants. Also fertilized plants with $50 \%$ organic $+50 \%$ inorganic recorded the highest significant values of most aforementioned parameters compared with control. The best results of both vegetative growth parameters and chemical constituents of leaves were recorded when plants growing at $60 \mathrm{~cm}$ between them and fertilized by $50 \%$ organic as compost $+50 \%$ inorganic as ammonium nitrate (100 kg/fed.) and sprayed with garlic or yeast extracts at $2.5 \mathrm{~cm} / \mathrm{l}$ in both seasons. Therefore, this treatment could be recommended for improving squash plants performance under similar condition of this study.

Keywords: Summer squash, plant spacing, nitrogen fertilizer sources, organic farming, foliar application, garlic extract, yeast extract, vegetative growth, chemical constituents.
\end{abstract}

\section{INTRODUCTION}

Summer squash (Cucurbita pepo L.), is one of the most important crop of the family Cucurbitaceae, and of highly polymorphic vegetable grown during summer in tropical and subtropical condition. Plant density is one of the important aspect for production system of different crops. Optimum plant spacing ensures proper growth and development of plant resulting maximum yield of crop and economic use of land. Recent studies showed that increasing plant spacing within plants led to improvement growth of plants compared with the closer spacing (Fayed, 2010, Islam et al., 2011, Babayee et al., 2012).The excessive use of nitrogen fertilizer represents the major factor of plant production cost, increase soil salinity, lead to serious health 
hazards and creates some pollution of agro-ecosystem (Fisher and Richter, 1984). The optimum fertilizer requirements for summer squash production can be realized not only with the recommended quantity, but also through using proper sources that are considered one of the most important factors affecting the vegetative growth. Organic matter such as animal manure, green manure, plant residue and composted organic matter is accepted as a good soil management practice in sustainable crop production because it enhances soil fertility through the modification of soil physical, chemical and biological properties. (Asuegbu and Uzo, 1984 and El-Gizy, 1994).Moreover, organic manures play an important role in nutrients solubility and activate physiological and biochemical processes in plant leading to the increase in plant growth and nutrients uptake (Dahdouh et al., 1999 Sarhan et al., 2011, Adesina et al., 2011,).Recently, great attention has been focused on the possibility of using natural and salty substitute, i.e. dry yeast and garlic extracts as a substitute for artificial chemical fertilizers which have pollutant effects in the soil and plants and in turn, cause damage of the human health, foliar sprays of yeast or garlic extracts are used in vegetable crops production for stimulating and hastening plant growth, flowering and fruit set and consequently increasing early and total yield (Shafshak,2004, El-Sawy,2007; Shehata et al., 2012, Mahmoud et al., 2013). Hence, the objective of this work was to study the impact of organic, mineral fertilizers, plant spacing and foliar application of garlic and yeast extracts on growth and leaf nutrient composition of summer squash.

\section{MATERIALS AND METHODS}

This study was carried out during the two summer seasons of 2011 and 2012 at Sakha Agricultural Research Station Farm, Kafr El-Sheikh Governorate, Egypt on summer squash (Cucurbita pepo L.) El-Askandarani cultivar to study the impact of plant spacing, nitrogen fertilizer sources (organic and inorganic) and foliar spray with biostmulants and their interactions on vegetative parameters and leaf chemical constituents of summer squash.

The physical and chemical properties of the experimental soil are given in Table (1).

Table( 1):Physical and chemical and properties of experimental soil in 2011 and 2012 seasons.

\begin{tabular}{|c|c|c|c|c|c|c|c|c|c|c|}
\hline \multirow[t]{2}{*}{ Seasons } & \multirow[t]{2}{*}{$\begin{array}{l}\text { O.M } \\
(\%)\end{array}$} & \multirow[t]{2}{*}{$\begin{array}{l}\text { Clay } \\
(\%)\end{array}$} & \multirow[t]{2}{*}{$\begin{array}{l}\text { Silt } \\
(\%)\end{array}$} & \multirow[t]{2}{*}{$\begin{array}{l}\text { Sand } \\
(\%)\end{array}$} & \multirow[t]{2}{*}{$\begin{array}{c}\text { Texture } \\
\text { class }\end{array}$} & \multirow[t]{2}{*}{$\begin{array}{l}\text { E.C } \\
\text { (dS } \backslash \text { m) }\end{array}$} & \multirow[t]{2}{*}{ PH } & \multicolumn{3}{|c|}{$\begin{array}{c}\text { Available(Mg\Kg } \\
\text { soil) }\end{array}$} \\
\hline & & & & & & & & $\mathbf{N}$ & $\mathbf{P}$ & $\mathrm{K}$ \\
\hline & 1.96 & 5 & 23.92 & & & 4.9 & 7.7 & 26 & 9.5 & 50 \\
\hline nd & 2.12 & 43.22 & 24.20 & 32. & & 4.60 & 7.5 & 37 & 11 & 683 \\
\hline
\end{tabular}


The experimental layout was split-split plots system in a randomized complete block design with three replicates. Plant spacing $(30,45$ and $60 \mathrm{~cm}$ between plants) were randomly distributed in the main plots which were subdivided to three sub-plots, each one contained foliar application, i.e., control(water spray), yeast extract at rate $2.5 \mathrm{~cm} \backslash$ and garlic extract at rate $2.5 \mathrm{~cm} \backslash$ sprayed at three times (after two, four and six weeks from seed sowing date). while the nitrogen fertilizer sources (mineral and organic) were assigned to the sub-sub plots( Table 2). Mineral fertilizer as ammonium nitrate $(33.5 \% \mathrm{~N})$ was added in three equal portions after 2, 4 and 6 weeks from seed sowing date. Organic fertilizer (compost) was determined according to nitrogen percentage input (chemical analysis for total nitrogen) to provide $60 \mathrm{~kg} \mathrm{~N} / \mathrm{fed}$. The chemical analysis of compost is presented in Table (3)

This experiment included 45 different treatment combinations, each plot was comprised of three ridges $5 \mathrm{~m}$ length, $1 \mathrm{~m}$ width, the sub-sub plot area was $15 \mathrm{~m}^{2}$. Seeds were sown on $7^{\text {th }}$ and $10^{\text {th }}$ March in the first and second seasons, respectively

The normal cultural practices for the commercial summer squash production were followed according to the instructions advised by the Ministry of Agricultural

Table( 2):Quantity of organic and mineral fertilizers for the different nitrogen source treatments in 2012 and 2013 seasons.

\begin{tabular}{|l|c|c|c|}
\hline \multirow{2}{*}{ Fertilizer treatments } & \multicolumn{3}{|c|}{ Quantity of fertilizer } \\
\cline { 2 - 3 } & \multicolumn{2}{|c|}{ Compost ton/fed } & $\begin{array}{c}\text { Mineral fertilizer kg/fed. } \\
\text { ammonium nitrate }\end{array}$ \\
\cline { 2 - 3 } & $\mathbf{2 0 1 1}$ & $\mathbf{2 0 1 2}$ & - \\
$100 \%$ organic (compost) & 5 & 4.60 & 200 \\
$100 \%$ mineral & - & - & 50 \\
$75 \%$ organic + $5 \%$ & 3.75 & 3.45 & 150 \\
mineral & 1.25 & 1.15 & 100 \\
$75 \%$ mineral $+25 \%$ organ & 2.5 & 2.3 & \\
$50 \%$ organic + 50\% & & & \\
mineral & & & \\
\hline
\end{tabular}

Table( 3): chemical analysis of compost during 2011 and 2012 seasons.

\begin{tabular}{|l|c|c|c|c|}
\hline Seasons & \multicolumn{3}{|c|}{ Macro-elements (\%) } & \multirow{2}{*}{ O.M(\%) } \\
\hline & $\mathrm{N}$ & $\mathrm{P}$ & $\mathrm{K}$ & \\
\hline $1^{\text {st }}$ & 1.2 & 0.48 & 0.75 & 37.5 \\
\hline $2^{\text {nd }}$ & 1.3 & 0.49 & 0.76 & 38.2 \\
\hline
\end{tabular}


Data recorded:

Growth parameters:

A random sample of five plants were taken from each plot at 50 days after sowing (DAS) in both seasons of the study for measuring the growth parameters of summer squash plants, i.e., Plant fresh and dry weight (g), No. of leaves/plant, Leaf area/plant $\left(\mathrm{cm}^{2}\right)$ was calculated according to Koller (1972) and total chlorophyll was measured by A Minolta SPAD chlorophyll meter (Yadava, 1986).

\section{Chemical constituents of leaves:}

The samples of leaves was randomly taken for estimating minerals content. In addition, nitrogen was determined by using the Micro-Kjeldahl method (Piper, 1950). Phosphorus was determined by using the spectrophotometers (King, 1951). Potassium was determined according to (Jackson, 1967).Iron, manganese and zinc were determined according to Chapman and Pratt (1978).

Statistical analysis:

Data were tested by analysis of variance according to Little and Hills (1975). Duncan's Multiple Range test was used for comparison among treatments means (Duncan, 1955).

\section{RESULTS AND DISCUSSION}

\section{Growth parameters}

Effect of plant spacing:

Data presented in Table (4) show that growth parameters was significantly affected by plant spacing in the two growing seasons. The results indicated that increasing plant spacing from 30 to $60 \mathrm{~cm}$ increased values of plant growth parameters. The decreasing in plant growth due to decrease plant spacing might be attributed to the high competition for nutrients and water among plants with the adjoining plants in the row (Kultur et al., 2001). In the same tendency, Dimitrov and Kanzirska (1995); Saad (2002); Ban et al. (2006); Fayed (2010); Islam et al. (2011) and Babayee et al. (2012), reported that growth parameters of squash plants were increased with increasing plant spacing.

\section{Effect of foliar application:}

Comparing the effect of foliar application treatments (yeast and garlic extracts), it was found that all growth parameters were increased in response to spraying all foliar in the two growing seasons as compared to the check treatment (control). Data in Table (4) clearly show that the highest significant values of the aforementioned parameters were recorded by spraying plant with garlic extracts following by spraying yeast extract, while the check treatment (control) recorded the lowest values of vegetative parameters in both seasons. Regarding the growth enhancing potential of garlic or yeast extract might be attributed to being contain natural sources of many growth promoting substances (macro and micronutrients, IAA,) (El-Desouky et al., 1998 and Nagodawithana, 1991). These results are in harmony with the findings of Helmy (1992) on summer squash; El-Ghamriny et al. (1999) on 
tomato; El-Sawy (2007) on cucumber; Shehata et al. (2012) on cucumber and Swelam (2012) on pepper plants.

Table (4): Effect of plant spacing, foliar application and nitrogen fertilizer sources on vegetative growth characters of summer squash during 2011 and 2012 summer season.

\begin{tabular}{|c|c|c|c|c|c|c|c|c|c|c|}
\hline \multirow[t]{2}{*}{ Treatments } & \multicolumn{2}{|c|}{$\begin{array}{l}\text { Plant fresh } \\
\text { weight }(g)\end{array}$} & \multicolumn{2}{|c|}{$\begin{array}{l}\text { Plant dry } \\
\text { weight }(g)\end{array}$} & \multicolumn{2}{|c|}{$\begin{array}{l}\text { No. of leave } \\
\text { /plant }\end{array}$} & \multicolumn{2}{|c|}{$\begin{array}{c}\text { Plant leaf area } \\
\left(\mathrm{cm}^{2}\right)\end{array}$} & \multicolumn{2}{|c|}{$\begin{array}{c}\text { Total } \\
\text { chlorophyll } \\
\text { (SPAd) }\end{array}$} \\
\hline & 2011 & 2012 & 2011 & 2012 & 2011 & 2012 & 2011 & 2012 & 2011 & 2012 \\
\hline \multicolumn{11}{|l|}{ Plant spacing (cm) } \\
\hline 30 & $334.39 \mathrm{~b}$ & $324.36 \mathrm{c}$ & $39.34 \mathrm{~b}$ & $38.21 \mathrm{c}$ & $21.71 \mathrm{~b}$ & $21.06 \mathrm{~b}$ & $2843.26 \mathrm{~b}$ & $2735.71 \mathrm{~b}$ & $35.13 \mathrm{c}$ & $33.51 \mathrm{c}$ \\
\hline 45 & $356.28 \mathrm{a}$ & $345.57 \mathrm{~b}$ & $41.93 \mathrm{a}$ & $40.72 \mathrm{~b}$ & $23.03 \mathrm{a}$ & $22.42 \mathrm{a}$ & $3027.21 \mathrm{a}$ & $2914.28 \mathrm{a}$ & $40.33 \mathrm{~b}$ & $39.42 \mathrm{~b}$ \\
\hline 60 & $361.59 \mathrm{a}$ & $350.85 \mathrm{a}$ & $42.63 \mathrm{a}$ & $41.54 \mathrm{a}$ & $23.12 \mathrm{a}$ & $22.35 \mathrm{a}$ & $3075.04 \mathrm{a}$ & $2985.09 \mathrm{a}$ & $45.42 \mathrm{a}$ & $44.08 \mathrm{a}$ \\
\hline F. test & ** & *夫 & ** & *夫 & ** & ** & ** & *夫 & ** & ** \\
\hline \multicolumn{11}{|l|}{ Foliar application } \\
\hline Control & $315.85 \mathrm{c}$ & $308.55 \mathrm{c}$ & $37.13 \mathrm{c}$ & $36.03 \mathrm{c}$ & $21.66 \mathrm{~b}$ & $21.05 c$ & $2684.76 \mathrm{c}$ & $2606.46 \mathrm{c}$ & $38.53 c$ & $36.88 \mathrm{c}$ \\
\hline Yeast extract & $358.46 \mathrm{~b}$ & $347.86 \mathrm{~b}$ & $42.28 \mathrm{~b}$ & $41.14 \mathrm{~b}$ & $22.82 \mathrm{a}$ & $22.16 \mathrm{~b}$ & $3046.23 \mathrm{~b}$ & $2954.23 \mathrm{~b}$ & $40.65 \mathrm{~b}$ & $39.46 \mathrm{~b}$ \\
\hline Garlic extract & $377.97 \mathrm{a}$ & $364.38 \mathrm{a}$ & $44.49 \mathrm{a}$ & $43.41 \mathrm{a}$ & $23.29 \mathrm{a}$ & $22.61 \mathrm{a}$ & $3214.52 \mathrm{a}$ & $3073.88 \mathrm{a}$ & $41.68 \mathrm{a}$ & $40.67 \mathrm{a}$ \\
\hline F. test & ** & ** & ** & ** & ** & ** & ** & ** & ** & ** \\
\hline \multicolumn{11}{|l|}{$\mathrm{N}$ fertilizer sources } \\
\hline $100 \%$ inorganic & $350.14 \mathrm{c}$ & $339.63 \mathrm{bc}$ & $41.21 \mathrm{c}$ & $40.32 \mathrm{~b}$ & $22.60 \mathrm{bc}$ & $21.99 \mathrm{bc}$ & $2983.41 \mathrm{c}$ & $2860.61 \mathrm{bc}$ & $40.11 \mathrm{bc}$ & $39.12 \mathrm{c}$ \\
\hline $\begin{array}{l}75 \% \text { inorganic }+25 \% \\
\text { organic }\end{array}$ & $358.74 \mathrm{~b}$ & $347.97 \mathrm{ab}$ & $42.22 \mathrm{~b}$ & $40.98 \mathrm{~b}$ & $23.01 \mathrm{~b}$ & $22.36 \mathrm{~b}$ & $3050.02 b$ & $2958.65 \mathrm{ab}$ & $40.73 b$ & $39.41 \mathrm{~b}$ \\
\hline $\begin{array}{l}75 \% \text { organic }+25 \% \\
\text { inorganic }\end{array}$ & $343.11 \mathrm{~d}$ & $332.95 \mathrm{c}$ & $40.45 \mathrm{~d}$ & $39.31 \mathrm{c}$ & $22.18 \mathrm{c}$ & $21.50 \mathrm{c}$ & $2914.69 \mathrm{~d}$ & $2790.27 \mathrm{c}$ & $39.82 \mathrm{c}$ & $38.47 d$ \\
\hline $\begin{array}{l}50 \% \text { organic }+50 \% \\
\text { inorganic }\end{array}$ & $365.82 \mathrm{a}$ & $351.11 \mathrm{a}$ & $43.06 \mathrm{a}$ & $41.75 \mathrm{a}$ & $23.97 \mathrm{a}$ & $23.28 \mathrm{a}$ & $3107.78 \mathrm{a}$ & $3014.58 \mathrm{a}$ & $41.78 \mathrm{a}$ & $40.16 \mathrm{a}$ \\
\hline $100 \%$ organic & $336.01 \mathrm{e}$ & $329.64 \mathrm{c}$ & $39.58 \mathrm{e}$ & $38.41 \mathrm{~d}$ & $21.18 \mathrm{~d}$ & $20.57 d$ & $2853.30 \mathrm{e}$ & $2767.74 \mathrm{c}$ & $39.01 \mathrm{~d}$ & $37.88 \mathrm{e}$ \\
\hline F. test & ** & ** & ** & ** & ** & ** & ** & ** & ** & ** \\
\hline
\end{tabular}

\section{Effect of fertilizer treatments:}

Data presented in Table 4 reveal that the highest values of plant growth parameters (plant fresh and dry weight, No. of leaves, plant leaf area and total chlorophyll) were produced by plants fertilized with $50 \%$ organic + $50 \%$ inorganic fertilizer treatment followed by $75 \%$ inorganic $+25 \%$ organic, while the lowest values were obtained by $100 \%$ organic fertilizer treatment. Improving vegetative growth parameters due to treatment of compost plus chemical $\mathrm{N}$ fertilizer compared with using each alone can be attributed to that applying mineral $\mathrm{N}$ stimulated the rate of decomposition of compost and produced higher humus substances which in turn improve the physical and chemical properties of the soil as well as increase both the exchangeable water soluble of nutrients and their uptake (Cooke, 1972). Consequently, vegetative growth parameters would be increased. In this concern, Mafadi and Gohar (1975) attribute this action due to adsorption $\mathrm{NH}^{+}$ion on the surface of compost and became available to plant uptake. Similarly, Jha et al. (1996) stated that applying chemical fertilizer with organic manures increased both $\mathrm{N}$ mineralization and nitrification which in turn enhance the access to $\mathrm{NH}_{4}-\mathrm{N}$ and result in greater number of viable cells of nitrifying bacteria, especially with chemical fertilization. The superiority of $50 \%$ inorganic $\mathrm{N}+50 \%$ compost treatment in enhancing vegetative growth of summer squash plants may be due to that such organic manure is capable as a source of many essential 
macro and micronutrients to plants (Remington and Frances, 1955) to serve as a good natural soil texture conditioner being rich in organic matter and increase availability and uptake of NPK which positively reflected on plant cell elongation and division as well as stimulate photosynthesis and metabolic processes. The obtained results are in accordance with those of Abd El-Kawy (2003); Saad (2002); Ghoname and Shafeek (2005); Hanna et al. (2005); Farrag (2009) and Swelam (2012); Baghdadi et al. (2012); Shehata et al. (2012); Mahmoud et al. (2013)

Effects of interactions between each two of plant spacing, foliar application and fertilizer treatments.

Data presented in Table (5) noticed that the highest values of growth parameters were recorded by the plants planted at spacing $60 \mathrm{~cm}$ and sprayed with garlic extract followed by yeast extract treatment. On the other hand, the lowest values recorded by plants at spacing $30 \mathrm{~cm}$ and sprayed with water. Meanwhile, the plants grown at spacing $60 \mathrm{~cm}$ and fertilized with $50 \%$ inorganic $+50 \%$ organic tended to increase the growth parameters in both seasons compared to the lowest values in this respect obtained by plants growing at $30 \mathrm{~cm}$ and fertilized with $100 \%$ organic treatment. Regarding interactions between foliar application and fertilizer treatments, data in the same table showed that, fertilized plants with $50 \%$ organic $+50-\%$ inorganic and sprayed with garlic extract had better vegetative growth parameters .

Effect of interaction among plant spacing, foliar application and fertilizer treatments:

Data in Table (6) show that, there were significant differences in plant fresh, dry weight and plant leaf area due to the combination interaction among plant spacing, foliar and $\mathrm{N}$ fertilizer sources treatments in both seasons. On the other hand, the differences were not significant as for no. of leaves/plant in both seasons and in the first seasons as for total chlorophyll. The highest plant fresh and dry weight and largest leaf area was achieved by planting summer squash plants at spacing $60 \mathrm{~cm}$ and fertilized with $50 \%$ inorganic $+50 \%$ organic and sprayed with garlic extracts compared with the lowest values in this respect produced by plants at $30 \mathrm{~cm}$ spacing and fertilized with $100 \%$ organic without spraying.

\section{Chemical constituents of leaves}

Effect of plant spacing:

Chemical constituents (N, P, K, Fe, Zn and Mn) concentrations of squash leaves were reflected successive and significant increments with increasing plant spacing in both seasons. Table 7 showsthat summer squash planted at $60 \mathrm{~cm}$ spacing gave the highest elements percentage in leaves followed by $45 \mathrm{~cm}$ spacing compared to the lowest percentage resulted by 30 $\mathrm{cm}$ spacing treatment. Increasing plant density decreased $\mathrm{N}, \mathrm{P}, \mathrm{K}$, and $\mathrm{Fe}$, $\mathrm{Zn}$ and $\mathrm{Mn}$ content. This may be due to the increased competition between and within plants. In this concern, Hanaa and Adams (1992), Sanders et al. (1993), Saad (2002) found that increasing plant spacing improvement the elements content in leaves of pumpkin plants. 
J. Plant Production, Mansoura Univ., Vol. 4 (11), November, 2013

T5 
Tartoura, E A. A et al.

T6

1698 


\section{Effect of foliar application:}

Data in Table (7) show that garlic extract foliar application treatment increased leaves mineral contents followed by yeast extract foliar application compared to the lowest one obtained by control treatment. Improving mineral leaves contents of summer squash plants by garlic or yeast extract treatment, may be due to presence of macro and micro-nutrients in the extracts of garlic or yeast. Similarly, El-Ghamriny et al. (1999) on tomato; Shafshak et al. (2004) on squash plants; El-Sawy (2007) and Shehata et al. (2012) on cucumber plants, found that the spraying of garlic or yeast extract improved leaves and seed mineral contents.

Effect of fertilizer treatments:

As for the effect of $\mathrm{N}$ fertilizer sources on chemical constituents of leaves, data in Table (7) show that, squash plant fertilized with $50 \%$ organic + $50 \%$ inorganic treatment gave the highest $\mathrm{N}, \mathrm{P}, \mathrm{K}, \mathrm{Fe}, \mathrm{Zn}$ and $\mathrm{Mn}$ leaf contents compared with the lowest mineral contents $100 \%$ organic treatment in both seasons.In the same tendency, Alphons and Saad (2000) on cucumber; Adam et al. (2002); Farrag (2009), on cantaloupe, Taha et al. (2011) on squash found that fertilizing plants with organic plants increased macro- and microelements contents in leaves and seed.

Effects of interactions between each two of plant spacing, foliar application and fertilizer treatments.

Data in Table (8) clear that, the combined interaction between plant spacing at $60 \mathrm{~cm}$ plus foliar garlic extracts gave the highest percentage of macro and microelements in leaves compared to the lowest values obtained by squash plants growing at $30 \mathrm{~cm}$ without spraying (control).As for, the combined interaction between plant spacing and fertilizer treatments, data presented in Table (8) show that the highest values of N, P, K, Fe, Zn and Mn contents in leaves were achieved by plant spacing $60 \mathrm{~cm}$ plus applying $50 \%$ organic. $+50 \%$ inorganic fertilizers in both seasons except as for $P$ in the first season. Regarding effect of the interaction between foliar application and fertilizer treatments on chemical constituents of leaves, data in Table (8) show that there were non-significant differences about $\mathrm{N} \%, \mathrm{P} \%$ in the first season and $\mathrm{K} \%$ in the second season. Meanwhile, the differences were not affected as for $\mathrm{Fe}$ and $\mathrm{Mn}$ in both seasons. The plants fertilized with $50 \%$ organic $+50 \%$ inorganic plus sprayed with garlic extract gave the highest values in this respect.

Effect of interaction among plant spacing, foliar application and fertilizer treatments.

As for the effect of the interaction among plant spacing, foliar application and $\mathrm{N}$ fertilizer on chemical constituents of summer squash leaves during 2011 and 2012 seasons, data in Table (9) declared that, the squash plants growing at $60 \mathrm{~cm}$ and fertilized with $50 \%$ inorganic $+50 \%$ organic and sprayed with garlic extract tended to increase the leaves mineral contents (N, P, K, Fe, Zn and Mn). 
Tartoura, E A. A et al. 
J. Plant Production, Mansoura Univ., Vol. 4 (11), November, 2013 
Tartoura, E A. A et al. 


\section{REFERENCES}

Abd El-Kawy, T.F.A. (2003). The effect of some organic and inorganic fertilizers on plant growth and fruit quality of cucumber plant under plastic house. M.Sc. Thesis, Fac. Agric., Ain Shams Univ., Egypt.

Adam, S.M.; A.M. Abdalla and F.A. Rizk, (2002). Effect of interaction between the mineral and biofertilizer on the productivity of cantaloupe (Cucumis melo L.) under the newly reclaimed soil conditions. Egypt J. Hort., 29(2): 301-315.

Adesina, G.O.; W.B. Akanbi; O.S. Olabode and O. Akintoye (2011). Effect of water hyacinth and neem based composts on growth, fruit yield and quality of cucumber (Cucumis sativus). Africana J. of Agric. Res. 6(3): 6477-6484.

Babayee, S.A.; J. Daneshian; H. Beghadadi and M. Yousefi (2012). Effect of plant density and irrigation interval on agronomical traits of (Cucurbita pepo L.) Technical J. of Engineering and Applied Sci. 208: 258-261

Baghdadi, H.; J. Daneshian; M. Yousefi; M. Alimohamadi and M. Kheybari (2012). Influence of cattle manure and mycorrhiza fungi on vegetative growth of pumpkin under water deficit condition. International J. Agric. Crop Sci., 4(18): 1362-1363.

Chapman, H.D. and P.F. Pratts( 1987). Methods of analysis for soils, plant and water. Univ. California USA.

Cooke, G.W., 1972. Fertilizer for maximum yield. Richard Clay, The Chancer Press Ltd. Hungary, Suffolk. Britain, pp. 458.

Dahdouh, S.M.; F.A. Ahmed and F.M. Salem, (1999). Effect of organic manure and foliar application of some macro and micronutrient on wheat. Zagazig J. Agric. Res., 26(2): 445-456.

Dimitroy, P. and V. Kanazirska, (1997). Optimization of the density of January planted glasshouse cucumbers (Hort. Abst., 67(4): 3026.

Duncan, D.B., (1955). Multiple Range and Multiple F.test.Biometrics,11: 1-42.

El-Ghamriny, E.A.; H.M. Arisha and K.A. Nour, (1999). Studies on tomato flowering, fruit set, yield and quality in summer seasons, Zagazig $\mathrm{J}$. Agric. Res., 26(5): 1345-1364.

El-Gizy, S. M. (1994). Comparative study for influence of manure sources on growth, yield and pod quality of pea. Minufiya J. Agric Res., 19(6): 3243-57.

El-Sawy, M.B. (2007). Effect of mulch and foliar spray with biostimulants and chemical nutrients on cucumber plants grown under plastic houses. Ph.D. Thesis, Fac. Agric., Kafrelsheikh Univ., Egypt.

Farrag, D.E. (2009). Effect of organic and mineral fertilizers and biostimulants on growth, yield and quality of cantaloupe plant (Cucumis melo var. cantaloupensis, L.). Ph.D. Fac. Agric. Kafrelsheikh Univ., Egypt.

Fayed, A.A.M. (2010). Response of sweet pepper to organic and mineral fertilization and some pruning treatments under plantic house. M.Sc. Thesis, Fac. Agric., Kafrelsheikh Univ., Egypt.

Ghoname, A. and M.R. Shafeek, (2005). Growth and productivity of pepper (Capsicum annuum L.) grown in plastic hours as affected by organic mineral and bio-N fertilizers. J. Agron., 4(4): 369-372. 
Hanna, H.Y. and A.J. Adams.(1992). Yield increase of staked cucumber by supplemental drip irrigation, reducing plant spacing and higher NPK rates. Proceedings of the Florida State Hort. Soc. 104: 240-244.

Hanna, M.M.; S.M. Kabeel and F.A. Darwish, (2005). Effect of organic and biofertilizer on growth, yield and fruit quality of cucumber (Cucumis sativus L.) growth under clear polyethylene low tunnels. J. Agric. Sci. Mansoura Univ., 30(5): 2827-2841.

Islam, M.; S. Saha; M.H. Akand and M.A. Rahim (2011). Effect of spacing on the growth and yield of pepper (Capsicum annuum L.). J. of Central. European Agric., 12(2): 328-335.

Jackson, M.L. (1967). Soil Chemical Analysis. Prentice Hall of India Private Limited, New Delhi.

Jha, P.B.; A.K. Kashyap and J.S. Singh, (1996). Effect of fertilizer and organic matter inputs on nutrifier population and $\mathrm{N}$-mineralization rates in a dry tropical region. Ind. Appl. Soil Eco., 4: 231-41.

King,E.J.(1951).Micro-analysis in Medical Biochemistry. $2^{\text {nd }}$ ed.Churchil, Lonon.

Koller,H.R (1972).Leaf area and leaf weight relationship in canopy. Crop Sci., 12:180-183.

Kultur, F. and H.C. Harrison; J.E. Stub (2001). Spacing and genotype affect fruit sugar concentration, yield and fruit size of muskmelon. Hort. Sci. 36(2): 274-278.

Little, T.M. and F.J. Hills (1975). Statistical Methods in Agriculture Research. California Univ., Davis.

Mahmoud, R.A.; M. El-Desouki; M. Abdel-Mouty and A.H. Ali (2013). Effect of compost and yeast extract application on the pea plant growth, pod yield and quality. J. of Applied. Sci. Res., 9(1): 149-155.

Mafadi, M.H. and H.O. Gohar. (1975). Corn response to potassium as influenced by watering period, farmyard manure, sodium and ammonia solution and the residual effect on subsequent wheat. Egypt. J. Soil Sci., Special Issue, 307.

Nagodawithana, W.T. (1991). Yeast Technology. Univ.Food Corporation Milwaukee, Wisconsin, Published by Van Nostrand Reinhold New York, p. 273.

Piper, C.S.(1950). Soil and Blant Analysis. Inter. Sci. Publisher Inc., New York.

Remington, J.S. and W. Frances(1955). The manure and fertilizer notebook. Ch. II. Page. 14. Teonard Hill Limited, Eden Street, N.W. pp. 123.

Saad, R.K. . (2002). Effect of plant population, biofertilizer and nitrogen on growth, fruit yield, seed production and seed quality of squash (Cucurbita pepo L.). Ph.D. Thesis, Fac. Agric., Alexandria Univ., Egypt.

Sander, D.C.; O.H. Bandele; C.H. Miller and A. Nash(1993). Nitrogen uptake within sequential vegetable cropping system. J. Plant Nutrition.

Sarhan, T.; G.H. Mohammed and J.A. Teli, (2011). Effect of bio and organic fertilizers on growth, yield and fruit quality of summer squash. Sarhad J. Agric. 271(3): 377-383. 
Shafshak, N, S.; A.R.A. Aggour and S.M.M. Ali (2004). Effect of fertilization system on some squash cultivars production. The 4th Scientific Conference of Agric. Sci., Assiut, December, pp. 418-426.

Shehata, S.A.; Y.M. Ahmed; E.T. Youssef and M.A. Azoz (2012). Influence of some organic and inorganic fertilizer on vegetative growth, yield and yield components of cucumber plants. Research J. of Agric. and Biological Sci., 8(2): 108-114.

Swelam, W.M.E. (2012). Effect of organic fertilizer, biofertilizer and some foliar application treatmetns on the yield and quality of sweet pepper. Ph.D. Thesis, Fac. Agric., Mansoura Univ., Egypt.

Taha, Z.S.; H. Ghurbabt and A.T. Jiyan, (2011). Effect of bio- and organic fertilizers on growth, yield and fruit quality of summer squash. Sarhad J. Agric. 27, No.( 3).

Yadava, U.L.(1986). $\mathrm{H}$ rapid and non-destructive method to determine chlorophyll in intact leaves. HortScience, 21: 1449-1450.

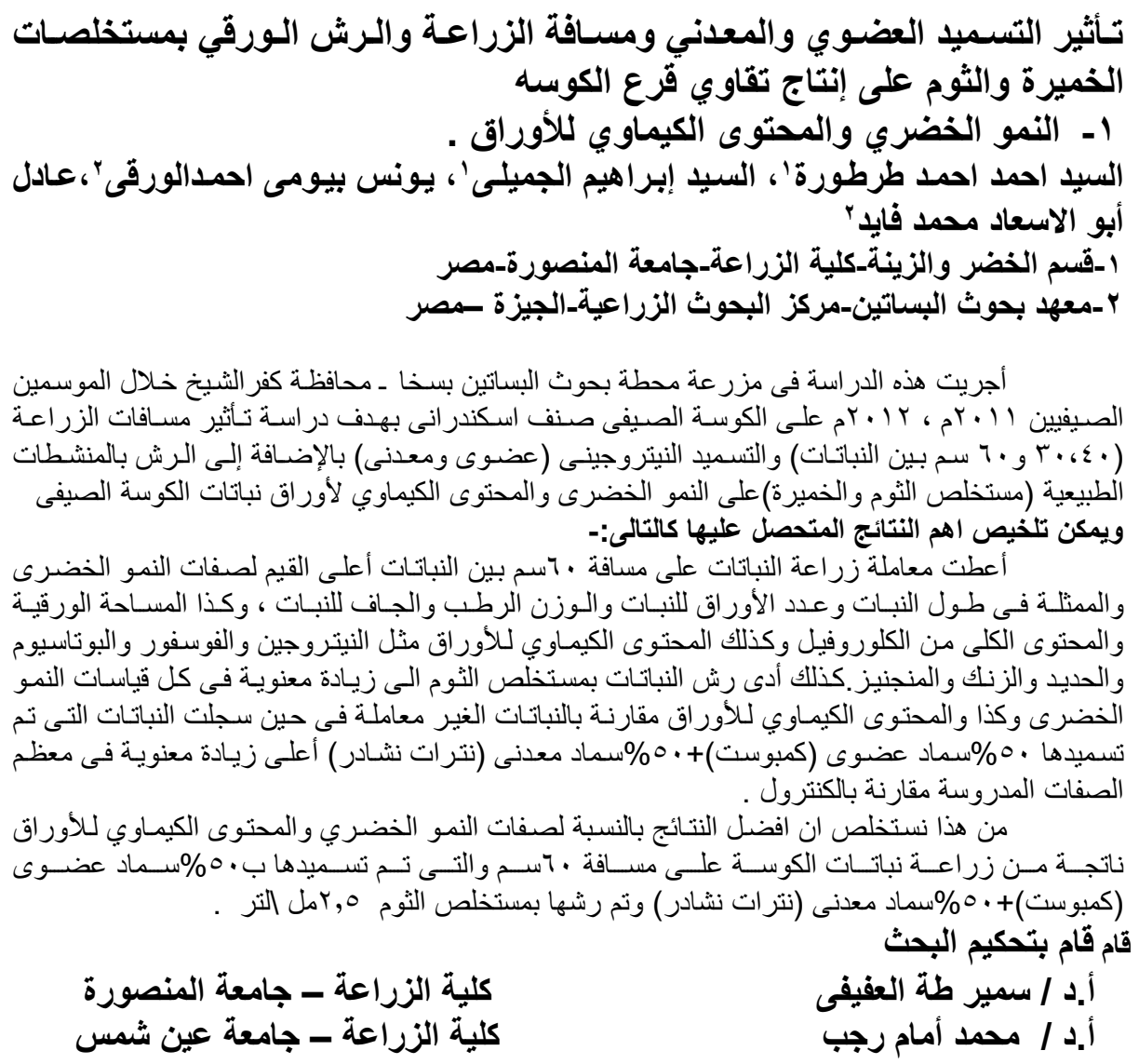


Table(5): Effects of interactions between each two of plant spacing, foliar application and nitrogen fertilizer sources on vegetative growth characters of summer squash during 2011 and 2012 seasons.

\begin{tabular}{|c|c|c|c|c|c|c|c|c|c|c|c|}
\hline \multirow{2}{*}{\begin{tabular}{|c|} 
\\
$\begin{array}{c}\text { Plant spacing } \\
\text { (cm) }\end{array}$ \\
\end{tabular}} & Treatment & \multicolumn{2}{|c|}{$\begin{array}{l}\text { Plant fresh weight } \\
(\mathrm{g})\end{array}$} & \multicolumn{2}{|c|}{$\begin{array}{l}\text { Plant dry weight } \\
\text { (g) }\end{array}$} & \multicolumn{2}{|c|}{$\begin{array}{c}\text { No. of leaves } \\
\text { /plant }\end{array}$} & \multicolumn{2}{|c|}{$\begin{array}{c}\text { Plant leaf area } \\
\left(\mathrm{cm}^{2}\right)\end{array}$} & \multicolumn{2}{|c|}{$\begin{array}{l}\text { Total chlorophyll } \\
\text { (SPAD) }\end{array}$} \\
\hline & $\begin{array}{l}\text { Foliar application and } N \\
\text { fertilizer source }\end{array}$ & 2011 & 2012 & 2011 & 2012 & 2011 & 2012 & 2011 & 2012 & 2011 & 2012 \\
\hline \multirow{2}{*}{30} & Control & $304.87 \mathrm{~d}$ & \begin{tabular}{|l|}
$295.73 \mathrm{f}$ \\
04
\end{tabular} & $35.81 \mathrm{~d}$ & $34.76 \mathrm{e}$ & $19.70 \mathrm{f}$ & $19.14 \mathrm{e}$ & \begin{tabular}{|l|}
$2589.18 \mathrm{e}$ \\
\end{tabular} & $2511.52 \mathrm{~d}$ & $32.51 \mathrm{~h}$ & $29.84 \mathrm{~h}$ \\
\hline & \begin{tabular}{|l} 
Yeast \\
Garlic
\end{tabular} & $\frac{328.00 \mathrm{c}}{370.30 \mathrm{ab}}$ & \begin{tabular}{|l}
$318.22 d$ \\
$358.14 \mathrm{bc}$
\end{tabular} & $\begin{array}{l}38.58 \mathrm{c} \\
43.61 \mathrm{ab}\end{array}$ & $\frac{37.43 \mathrm{~d}}{42.42 \mathrm{bc}}$ & $\frac{22.88 \mathrm{bcd}}{22.56 \mathrm{cde}}$ & $\frac{22.71 b c}{21.80 c d}$ & $\frac{2788.80 \mathrm{~d}}{3152.35 \mathrm{bc}}$ & $\begin{array}{l}2704.30 \mathrm{c} \\
2991.31 \mathrm{~b}\end{array}$ & $\frac{35.73 \mathrm{~g}}{37.14 \mathrm{f}}$ & $\frac{34.67 \mathrm{~g}}{36.04 \mathrm{f}}$ \\
\hline & Control & $320.38 \mathrm{c}$ & $310.69 \mathrm{e}$ & $37.69 \mathrm{c}$ & $36.58 \mathrm{~d}$ & $23.23 a b c$ & $22.60 \mathrm{ab}$ & $2727.10 \mathrm{~d}$ & $2645.26 \mathrm{c}$ & $39.12 \mathrm{e}$ & $37.94 \mathrm{e}$ \\
\hline \multirow[t]{2}{*}{45} & Yeast & $367.26 \mathrm{~b}$ & $356.24 \mathrm{c}$ & $43.21 \mathrm{~b}$ & $42.01 \mathrm{C}$ & $22.38 \mathrm{~b}-\mathrm{e}$ & $21.72 \mathrm{~cd}$ & $3121.80 \mathrm{c}$ & $3028.09 \mathrm{ab}$ & $40.22 d$ & $39.06 \mathrm{~d}$ \\
\hline & Garlic & $381.24 \mathrm{a}$ & $369.80 \mathrm{a}$ & $44.92 \mathrm{a}$ & $43.59 \mathrm{ab}$ & $23.48 \mathrm{ab}$ & $22.93 \mathrm{a}$ & $3232.72 \mathrm{ab}$ & $3069.48 \mathrm{ab}$ & $41.77 \mathrm{c}$ & $41.21 \mathrm{c}$ \\
\hline & Control & $322.30 \mathrm{c}$ & $319.24 \mathrm{~b}$ & $37.90 \mathrm{c}$ & $36.74 \mathrm{~d}$ & $22.04 \mathrm{e}$ & $21.40 \mathrm{~d}$ & $2738.00 \mathrm{~d}$ & $2662.60 \mathrm{c}$ & $44.12 \mathrm{~b}$ & $42.85 \mathrm{~b}$ \\
\hline 60 & Yeast & $380.13 \mathrm{ab}$ & $369.11 \mathrm{a}$ & $45.05 \mathrm{a}$ & $43.65 a b$ & $23.20 \mathrm{abc}$ & $22.56 \mathrm{ab}$ & $3228.64 \mathrm{ab}$ & $3131.81 \mathrm{a}$ & $46.03 \mathrm{a}$ & $44.65 \mathrm{a}$ \\
\hline \multirow{3}{*}{\begin{tabular}{|l} 
F. test. \\
Plant spacing \\
\end{tabular}} & Manilic & $302.35 \mathrm{~d}$ & $304.20 \mathrm{da}$ & $44.95 \mathrm{~d}$ & $44 . \angle 2 \mathrm{~d}$ & $23.84 \mathrm{a}$ & $23.10 \mathrm{~d}$ & & $3100.86 \mathrm{a}$ & $46.12 \mathrm{a}$ & $44.75 \mathrm{a}$ \\
\hline & $\mathrm{N}$ fertilizer sources & & & & & & & & & & \\
\hline & $100 \%$ inorg. & $338.81 \mathrm{e}$ & 328.63 & $39.78 d$ & $38.66 \mathrm{c}$ & 21.70 & 21.05 & $2878.20 \mathrm{c}$ & 2680.64 & 35.09 & $33.44 \mathrm{~L}$ \\
\hline \multirow{4}{*}{30} & $75 \%$ inorg $+25 \%$ org. & $340.52 \mathrm{e}$ & 330.28 & $40.07 \mathrm{~cd}$ & $38.90 \mathrm{C}$ & 21.92 & 21.28 & $2892.02 \mathrm{c}$ & 2805.27 & 35.67 & $34.11 \mathrm{k}$ \\
\hline & $75 \%$ org. $+25 \%$ inorg. & $324.83 \mathrm{f}$ & 315.05 & $38.22 \mathrm{e}$ & $37.22 \mathrm{~d}$ & 21.57 & 20.95 & $2769.01 \mathrm{~d}$ & 2685.31 & 34.74 & $33.16 \mathrm{~L}$ \\
\hline & $+50 \%$ inorg. & 344. & 334.54 & $40.60 \mathrm{~cd}$ & $39.34 \mathrm{C}$ & 22.93 & 22.14 & $02 c$ & 2844.28 & 36.71 & $34.46 j$ \\
\hline & $100 \%$ org. & $323.10 \mathrm{f}$ & & $38.02 \mathrm{e}$ & $36.91 \mathrm{~d}$ & 20.43 & 19.85 & $2745.38 \mathrm{~d}$ & 2663.05 & 33.42 & $32.43 \mathrm{~m}$ \\
\hline \multirow{4}{*}{45} & $100 \%$ inorg. & $358.41 \mathrm{~b}$ & 347.64 & $42.20 \mathrm{~b}$ & $40.94 \mathrm{~b}$ & 22.73 & 22.30 & $3054.01 \mathrm{~b}$ & 2962.44 & 39.63 & $39.57 \mathrm{~g}$ \\
\hline & $75 \%$ ino & 350 & 348.26 & $42.22 \mathrm{~b}$ & $41.08 \mathrm{~b}$ & 23.66 & 22.98 & $3052.10 \mathrm{~b}$ & 2960.38 & 41.04 & 39.987 \\
\hline & $75 \%$ org. & $346.72 \mathrm{~cd}$ & 336.15 & $40.79 \mathrm{c}$ & $39.56 \mathrm{c}$ & 22.62 & 21.87 & $2942.04 \mathrm{C}$ & 2743.04 & 39.82 & $8.65 \mathrm{~h}$ \\
\hline & $50 \%$ org. $+50 \%$ inorg. & $373.12 \mathrm{a}$ & 361.95 & $44.01 \mathrm{a}$ & $42.71 \mathrm{a}$ & 24.77 & 24.16 & $3167.27 \mathrm{a}$ & 3072.14 & 42.14 & $40.91 \mathrm{e}$ \\
\hline \multirow{5}{*}{60} & $\frac{100 \% \text { org. }}{100 \% \text { inor }}$ & $\frac{344 .}{353}$ & $\frac{333.86}{34261}$ & $40.49 \mathrm{~cd}$ & $39.34 \mathrm{c}$ & $\frac{21.36}{23.38}$ & $\frac{20.75}{20}$ & \begin{tabular}{|l|}
$2921.01 \mathrm{c}$ \\
$301013 \mathrm{~h}$
\end{tabular} & 2833.37 & 39.02 & $37.93 \mathrm{i}$ \\
\hline & $25 \%$ org. & $\frac{050.00}{376.73 a}$ & $\frac{042.01}{365.35}$ & $44.34 \mathrm{a}$ & $42.99 \mathrm{a}$ & $\frac{23.00}{23.42}$ & $\frac{2.05}{22.82}$ & 3206.15a & $\frac{251.15}{3110.15}$ & 45.46 & $44.13 \mathrm{~b}$ \\
\hline & $75 \%$ org. $+25 \%$ inorg. & $357.84 \mathrm{~b}$ & 347.72 & $42.37 \mathrm{~b}$ & $41.12 \mathrm{~b}$ & 22.35 & 21.67 & $3033.41 \mathrm{~b}$ & 2942.46 & 44.90 & $43.62 \mathrm{c}$ \\
\hline & $50 \%$ org. $+50 \%$ inorg. & $379.32 \mathrm{a}$ & 356.83 & $44.58 \mathrm{a}$ & $43.20 \mathrm{a}$ & 24.21 & 23.53 & $3224.03 \mathrm{a}$ & 3127.32 & 46.46 & $45.11 \mathrm{a}$ \\
\hline & $100 \%$ org. & $340.91 \mathrm{de}$ & 341.75 & $40.27 \mathrm{~cd}$ & $39.00 \mathrm{c}$ & 21.76 & 21.12 & $2894.01 \mathrm{c}$ & 2806.80 & 44.62 & $43.32 \mathrm{~d}$ \\
\hline \multirow{2}{*}{\multicolumn{2}{|c|}{$\begin{array}{ll}\text { F. test } \\
\text { Foliar anplication } x \mathrm{x} \text { fertilizer sources }\end{array}$}} & & NS & & & NS & NS & & NS & NS & \\
\hline & & & & & & & & & & & \\
\hline \multicolumn{2}{|c|}{$\begin{array}{c}\text { Foliar application } \times \mathrm{N} \text { fertilizer sources } \\
\quad 100 \% \text { inorg. }\end{array}$} & $318.61 \mathrm{~g}$ & 309.07 & $37.42 \mathrm{~g}$ & 36. & 21.77 & 21.10 & $2715.01 \mathrm{~g}$ & $2644.18 \mathrm{~g}$ & 38.78 & $37.06 \mathrm{i}$ \\
\hline \multirow{3}{*}{ Control } & $75 \%$ inol & & 309.44 & & $36.42 \mathrm{~g}$ & 22.04 & & $2710.40 \mathrm{~g}$ & 2628 & 38.95 & $37.46 \mathrm{~h}$ \\
\hline & $\frac{75 \% \text { org. }+25 \% \text { inorg. }}{50 \% \text { ora }+50 \% \text { inorg. }}$ & $309.41 \mathrm{~h}$ & 299.96 & $36.39 \mathrm{~h}$ & $35.32 \mathrm{~h}$ & 21.00 & 20.35 & $2629.06 \mathrm{~h}$ & $2550.05 \mathrm{~g}$ & 37.87 & $36.22 j$ \\
\hline & $\begin{array}{l}50 \% \text { org. }+50 \% \text { inorg. } \\
100 \% \text { org. }\end{array}$ & $\frac{323.90 \mathrm{~g}}{302.12 \mathrm{~h}}$ & $\frac{314.12}{31017}$ & $38.04 \mathrm{~g}$ & $36.91 \mathrm{~g}$ & 23.24 & 22.68 & $2753.22 \mathrm{~g}$ & $2670.73 \mathrm{fg}$ & 40.14 & $37.74 \mathrm{~h}$ \\
\hline \multirow{5}{*}{ Yeast } & $100 \%$ org. & & $\begin{array}{l}310.11 \\
347.75\end{array}$ & $\begin{array}{r}36.30 \mathrm{~h} \\
42.20 \mathrm{de}\end{array}$ & $\begin{aligned} 35.17 \mathrm{~h} \\
40.88 \mathrm{de}\end{aligned}$ & $\frac{20.23}{22.68}$ & $\begin{array}{l}19.68 \\
22.02\end{array}$ & $2617.12 \mathrm{~h}$ & $\frac{2538.58 \mathrm{~g}}{2956.33 \mathrm{c}}$ & 36.97 & $35.92 \mathrm{k}$ \\
\hline & $75 \%$ inorc & $372.61 \mathrm{c}$ & 361.40 & $43.83 \mathrm{c}$ & $42.63 \mathrm{c}$ & 23.71 & $\frac{2 c .0 c}{23.12}$ & \begin{tabular}{|l|l|l}
$3167.20 \mathrm{c}$ \\
\end{tabular} & 3071 & 40.96 & $\begin{array}{l}39.51 \mathrm{e} \\
39.75 \mathrm{e}\end{array}$ \\
\hline & $75 \%$ org. + & $349.54 \mathrm{e}$ & 339.68 & $41.50 \mathrm{e}$ & $40.26 \mathrm{e}$ & 22.00 & 21.31 & $2967.14 \mathrm{e}$ & $8 \mathrm{de}$ & 40.27 & $39.09 \mathrm{f}$ \\
\hline & $50 \%$ org. $+50 \%$ inorg. & $372.23 c$ & 361.07 & $43.83 \mathrm{c}$ & $42.51 \mathrm{C}$ & 23.95 & 23.30 & $3164.30 \mathrm{c}$ & $3068.80 \mathrm{bc}$ & 41.68 & $40.43 \mathrm{c}$ \\
\hline & $100 \%$ or & & & & & 21. & & $05 \mathrm{f}$ & 0 ef & 39.27 & $38.53 \mathrm{~g}$ \\
\hline \multirow{5}{*}{ Garlic } & $100 \%$ inors & $373.32 \mathrm{c}$ & 362.05 & & $43.78 \mathrm{~b}$ & 23.35 & 22.86 & $3188.60 \mathrm{c}$ & $2981.28 \mathrm{~cd}$ & 40.86 & $40.74 \mathrm{~b}$ \\
\hline & $75 \%$ inorg & $384.61 \mathrm{~b}$ & 373.06 & $45.27 \mathrm{~b}$ & $43.92 \mathrm{~b}$ & 23.25 & 22.54 & $3273.25 \mathrm{~b}$ & $3175.20 \mathrm{ab}$ & 42.25 & $41.12 \mathrm{~b}$ \\
\hline & $75 \%$ org. $+25 \%$ inorg. & $370.44 \mathrm{c}$ & 359.27 & $43.49 \mathrm{c}$ & $42.32 \mathrm{c}$ & 23.55 & 22.84 & $3148.21 \mathrm{c}$ & $2943.07 \mathrm{~cd}$ & 41.33 & $40.11 \mathrm{~d}$ \\
\hline & $50 \%$ org. $+50 \%$ inorg. & $401.35 \mathrm{a}$ & 378.13 & $47.31 \mathrm{a}$ & $45.83 a$ & 24.72 & 23.85 & $3406.28 \mathrm{a}$ & $3304.22 \mathrm{a}$ & 43.57 & $42.31 \mathrm{a}$ \\
\hline & $100 \%$ org. & $360.21 \mathrm{~d}$ & 349.38 & $42.42 \mathrm{~d}$ & $41.21 \mathrm{~d}$ & 21.57 & 20.95 & $3057.24 \mathrm{~d}$ & $2965.64 \mathrm{~cd}$ & 40.37 & $39.22 f$ \\
\hline \multicolumn{2}{|l|}{ F. test } & & NS & & & NS & NS & & & NS & \\
\hline
\end{tabular}


Table(6): Effects of interactions among plant spacing, foliar application and nitrogen fertilizer sources on vegetative characters of summer squash during 2011 and 2012 seasons.

\begin{tabular}{|c|c|c|c|c|c|c|c|c|c|c|c|c|}
\hline \multicolumn{3}{|c|}{ Treatment } & \multicolumn{2}{|c|}{ Plant fresh weight $(\mathrm{g})$} & \multicolumn{2}{|c|}{ Plant dry weight (g) } & \multicolumn{2}{|c|}{ No. of leaves/plant } & \multicolumn{2}{|c|}{ Plant leaf area $\left(\mathrm{cm}^{2}\right)$} & \multicolumn{2}{|c|}{$\begin{array}{l}\text { Total chilorophyll } \\
\text { SPAD }\end{array}$} \\
\hline $\begin{array}{c}\text { Plant } \\
\text { spacing, } \\
\text { cm }\end{array}$ & $\begin{array}{l}\text { Foliar } \\
\text { applic. }\end{array}$ & $\mathrm{N}$ fertilizers sources & 2011 & 2012 & 2011 & 2012 & 2011 & 2012 & 2011 & 2012 & 2011 & 2012 \\
\hline \multirow{14}{*}{30} & \multirow{4}{*}{ Control } & $100 \%$ inorg. & $313.82 n$ & \begin{tabular}{|l|l}
$304.60 \mathrm{no}$ \\
30.612
\end{tabular} & $36.67 p$ & $35.57 \mathrm{~m}$ & 19.76 & 19.20 & $2665.10 p$ & $2584.40 \mathrm{mno}$ & 32.42 & $29.59 \mathrm{~s}$ \\
\hline & & $\begin{array}{l}75 \% \text { inorg }+25 \% \text { org. } \\
75 \% \text { org. }+25 \% \text { inorg. }\end{array}$ & $\begin{array}{l}314.94 \mathrm{n} \\
288.810 \\
\end{array}$ & \begin{tabular}{|l}
305.31 no \\
280.120 \\
\end{tabular} & $\begin{array}{l}37.03 p \\
33.93 q \\
\end{array}$ & $36.00 \mathrm{~m}$ & $\begin{array}{l}19.60 \\
19.56 \\
\end{array}$ & $\begin{array}{l}19.06 \\
19.00 \\
\end{array}$ & $\begin{array}{l}2669.21 \mathrm{p} \\
2454.30 \mathrm{q}\end{array}$ & $\frac{2588.90 \mathrm{mno}}{2380.63 \mathrm{o}}$ & $\begin{array}{l}32.97 \\
32.04\end{array}$ & $\frac{30.51 \mathrm{r}}{29.43 \mathrm{~s}}$ \\
\hline & & $50 \%$ org. $+50 \%$ inorg. & $315.62 n$ & $306.15 \mathrm{no}$ & $37.13 \mathrm{op}$ & $35.93 \mathrm{~m}$ & 21.56 & 20.93 & $2682.12 \mathrm{p}$ & $2601.73 \mathrm{~L}-\mathrm{O}$ & 34.65 & $30.15 \mathrm{r}$ \\
\hline & & $100 \%$ org. & 291.300 & 282.500 & $34.30 \mathrm{q}$ & $33.33 n$ & 18.00 & 17.53 & $2476.34 q$ & $2401.93 \mathrm{no}$ & 30.42 & $29.54 \mathrm{~s}$ \\
\hline & \multirow{5}{*}{ Yeast } & $100 \%$ inorg. & $327.62 \mathrm{Lmn}$ & $317.82 \mathrm{k}-\mathrm{n}$ & $38.57 \mathrm{mno}$ & $37.43 j-m$ & 22.50 & 21.83 & $2785.03 \mathrm{~m}-\mathrm{p}$ & $2701.00 \mathrm{klm}$ & 35.52 & $34.46 \mathrm{p}$ \\
\hline & & $75 \%$ inorg $+25 \%$ org. & $335.51 \mathrm{jkL}$ & \begin{tabular}{|l}
$325.44 j-n$ \\
31121
\end{tabular} & $39.43 \mathrm{klm}$ & $38.27 \mathrm{~h}-\mathrm{k}$ & 23.63 & 22.96 & $2851.40 \mathrm{k}-\mathrm{n}$ & $2765.86 j-m$ & 36.39 & 35.310 \\
\hline & & $75 \%$ org. $+25 \%$ inorg. & $320.83 \mathrm{mn}$ & \begin{tabular}{|l}
$311.21 \mathrm{mn}$ \\
321.11
\end{tabular} & 37.73 nop & $36.63 \mathrm{~km}$ & 22.66 & 22.06 & $2728.11 \mathrm{op}$ & $2644.46 \mathrm{k}-\mathrm{o}$ & $\frac{35.56}{36.71}$ & $34.52 p$ \\
\hline & & $50 \%$ org. $+50 \%$ inorg. & $341.41 \mathrm{jk}$ & $\frac{331.11 \mathrm{~h}-\mathrm{n}}{30550 \mathrm{n}}$ & $40.17 \mathrm{kl}$ & $38.90 \mathrm{hij}$ & $\frac{23.50}{2210}$ & 22.86 & 2901.15 jk & $2814.43 \mathrm{~g}-\mathrm{m}$ & $\frac{36.74}{31.45}$ & $\frac{35.690}{32.110}$ \\
\hline & & $100 \%$ org. & $314.82 n$ & \begin{tabular}{|l}
$305.50 \mathrm{no}$ \\
3625110
\end{tabular} & $37.03 \mathrm{op}$ & $35.93 \mathrm{~m}$ & $\frac{22.10}{202}$ & $\begin{array}{ll}21.43 \\
221.3\end{array}$ & $2676.27 p$ & $2595.74 \mathrm{~L}-0$ & $\begin{array}{ll}34.45 \\
37.32 \\
\end{array}$ & $33.41 \mathrm{q}$ \\
\hline & \multirow{5}{*}{ Garlic } & $100 \%$ inorg. & 374.71 efg & \begin{tabular}{|l|l|}
$363.51 \mathrm{c}-\mathrm{g}$ \\
36041
\end{tabular} & $44.10 \mathrm{e}-\mathrm{h}$ & $42.97 \mathrm{cde}$ & $\frac{22.83}{2352}$ & 22.13 & $3185.51 \mathrm{fgh}$ & $2756.53 \mathrm{i}-\mathrm{m}$ & 37.32 & $36.27 \mathrm{n}$ \\
\hline & & $75 \%$ inorg $+25 \%$ org. & 371.32 efg & \begin{tabular}{|l}
$360.14 \mathrm{c}-\mathrm{g}$ \\
252.10
\end{tabular} & $43.73 e^{-h}$ & $42.43 \mathrm{de}$ & 22.53 & 21.83 & $3156.13 \mathrm{fgh}$ & $3061.03 \mathrm{~d}-\mathrm{h}$ & 37.65 & $36.54 n$ \\
\hline & & $75 \%$ org. $+25 \%$ inorg. & $364.85 \mathrm{fgh}$ & $353.18 \mathrm{c}-\mathrm{i}$ & $43.00 \mathrm{ghi}$ & 42.07 def & 22.50 & 21.80 & $3124.41 \mathrm{gh}$ & $3030.83 \mathrm{~d}-\mathrm{h}$ & 36.64 & 35.550 \\
\hline & & $50 \%$ org. $+50 \%$ inorg. & 377.92 def & $366.42 \mathrm{~b}-\mathrm{f}$ & $44.50 \mathrm{~d}-\mathrm{g}$ & $43.20 \mathrm{~b}-\mathrm{f}$ & 23.73 & 22.63 & 3213.20 efg & $3116.70 c-f$ & 38.72 & $37.56 \mathrm{~m}$ \\
\hline & & $100 \%$ org. & $\frac{362.81 \mathrm{gh}}{32170 \mathrm{gn}}$ & $\frac{351.93 \mathrm{~d}-\mathrm{g}}{31211 \mathrm{mg}}$ & $42.73 \mathrm{hi}$ & $\begin{array}{l}41.47 \mathrm{ef} \\
36.77 \mathrm{~m}\end{array}$ & $\frac{21.20}{20202}$ & 20.60 & $3084.12 \mathrm{hi}$ & $291.46 \mathrm{~d}-\mathrm{j}$ & $\frac{35.37}{30.51}$ & $\frac{34.33 p}{3937}$ \\
\hline \multirow{14}{*}{45} & \multirow{5}{*}{ Control } & $100 \%$ inorg. & $321.70 \mathrm{mn}$ & $312.11 \mathrm{mn}$ & $37.90 \mathrm{~m}-\mathrm{p}$ & $36.77 \mathrm{~km}$ & $\frac{22.83}{2110}$ & 22.10 & 2757.62 mop & $2674.60 \mathrm{~km}$ & 39.54 & $38.37 \mathrm{~L}$ \\
\hline & & $75 \%$ inorg $+25 \%$ org. & $317.15 \mathrm{n}$ & 307.51 no & 37.27 op & $36.17 \mathrm{Im}$ & 24.10 & 23.46 & $2695.24 p$ & $2614.36 \mathrm{~L}-0$ & 39.49 & $38.75 \mathrm{KL}$ \\
\hline & & $75 \%$ org. $+25 \%$ inorg. & $\frac{317.13 \mathrm{n}}{32122 \mathrm{k} / \mathrm{m}}$ & $\begin{array}{l}307.22 \mathrm{no} \\
321.55 \mathrm{k}-\mathrm{n}\end{array}$ & $37.30 \mathrm{op}$ & $36.20 \mathrm{Im}$ & $\frac{22.36}{21463}$ & $\begin{array}{l}21.63 \\
21.23 \\
\end{array}$ & $2692.10 \mathrm{p}$ & $2611.63 \mathrm{~L}-0$ & 38.31 & $37.17 \mathrm{~m}$ \\
\hline & & $50 \%$ org. $+50 \%$ inorg. & $331.22 \mathrm{~km}$ & $321.55 \mathrm{k}-\mathrm{n}$ & $38.97 \mathrm{Lmn}$ & $37.87 \mathrm{i}-\mathrm{L}$ & $\frac{24.63}{2223}$ & 24.23 & $\frac{2816.31 \mathrm{~L}-\mathrm{O}}{267517 \mathrm{n}}$ & $2731.42 j-n$ & $\begin{array}{l}40.44 \\
3724 \\
\end{array}$ & $39.24 \mathrm{k}$ \\
\hline & & $\begin{array}{l}100 \% \text { o org. } \\
100 \% \text { inorg. }\end{array}$ & \begin{tabular}{|l}
$314.94 \mathrm{n}$ \\
372.61 efg
\end{tabular} & $\begin{array}{l}305.40 \mathrm{no} \\
361.50 \mathrm{c}-\mathrm{g}\end{array}$ & 37.03 op & $\begin{array}{l}35.93 \mathrm{~m} \\
42.53 \mathrm{de}\end{array}$ & $\frac{22.23}{21.86}$ & $\frac{21.60}{21.30}$ & $\begin{array}{l}26 / 5.1 / \mathrm{p} \\
3176.25 \mathrm{fgh}\end{array}$ & $\frac{2594.30 \mathrm{~L}-\mathrm{O}}{3072.46 \mathrm{C}-\mathrm{g}}$ & $\begin{array}{l}37.24 \\
40.33\end{array}$ & $\frac{36.22 n}{39.23 k}$ \\
\hline & \multirow{4}{*}{ Yeast } & $75 \%$ inorg $+25 \%$ org. & & $358.70 \mathrm{c}-\mathrm{h}$ & $43.50 \mathrm{e}-\mathrm{h}$ & $42.63 \mathrm{de}$ & $\frac{1.00}{23.96}$ & 23.23 & $3143.14 \mathrm{fgh}$ & $3048.63 d-h$ & 40.42 & $39.21 \mathrm{k}$ \\
\hline & & $75 \%$ org. $+25 \%$ inorg. & $347.65 i$ & $337.13 \mathrm{~g}-\mathrm{h}$ & $40.87 \mathrm{jk}$ & $39.60 \mathrm{gh}$ & 20.80 & 20.03 & $2954.10 \mathrm{jk}$ & $2865.56 \mathrm{f}-\mathrm{L}$ & 39.55 & $38.44 \mathrm{~L}$ \\
\hline & & $50 \%$ org. $+50 \%$ inorg. & 382.81 cde & $371.30 \mathrm{~b}-\mathrm{f}$ & 45.10 cde & $43.77 \mathrm{bcd}$ & 24.53 & 23.86 & 3254.12 def & $3155.70 \mathrm{~b}-\mathrm{f}$ & 41.33 & $40.11 j$ \\
\hline & & & 363.64 jh & $352.71 \mathrm{c}-\mathrm{j}$ & $42.73 \mathrm{hi}$ & $41.50 \mathrm{ef}$ & 20.76 & 20.13 & $3091.18 \mathrm{hi}$ & $2998.10 \mathrm{~d}-\mathrm{i}$ & 39.51 & $38.35 \mathrm{~L}$ \\
\hline & \multirow{5}{*}{ Garlic } & $100 \%$ inorg. & 380.82 cde & $369.42 \mathrm{~b}-\mathrm{c}$ & $44.83 \mathrm{c}-\mathrm{f}$ & $43.53 \mathrm{bcd}$ & 23.50 & 23.50 & $3237.72 \mathrm{~d}-\mathrm{g}$ & 3140.26 cde & 39.05 & $41.12 i$ \\
\hline & & $75 \%$ inorg $+25 \%$ org. & $390.30 \mathrm{~cd}$ & 378.61 a-d & $45.90 \mathrm{~cd}$ & $44.47 \mathrm{bc}$ & 22.93 & 22.26 & 3317.05 de & $3218.18 \mathrm{a}-\mathrm{d}$ & 43.23 & $41.95 \mathrm{~h}$ \\
\hline & & $75 \%$ org. $+25 \%$ inorg. & 375.50 efg & $364.24 c-9$ & $44.20 \mathrm{e}-\mathrm{h}$ & $42.87 \mathrm{cde}$ & 24.70 & 23.96 & $3179.16 \mathrm{fgh}$ & $2751.93 \mathrm{i}-\mathrm{m}$ & 41.62 & $40.35 j$ \\
\hline & & $50 \%$ org. $+50 \%$ inorg. & $405.51 \mathrm{~b}$ & $393.43 \mathrm{ab}$ & $47.97 \mathrm{~b}$ & $46.50 \mathrm{a}$ & 25.16 & 24.40 & $3432.70 \mathrm{bc}$ & $3329.30 \mathrm{abc}$ & 44.65 & $43.37 \mathrm{fg}$ \\
\hline & & $100 \%$ org. & $354.06 \mathrm{hi}$ & $343.43 \mathrm{e}-\mathrm{k}$ & $41.70 \mathrm{ij}$ & $40.60 \mathrm{fg}$ & & & $2998.45 i j$ & $2907.73 e-k$ & 40.33 & $39.23 \mathrm{k}$ \\
\hline \multirow{15}{*}{60} & \multirow{5}{*}{ Control } & $100 \%$ inorg. & $320.16 \mathrm{mn}$ & $310.62 \mathrm{mn}$ & 37.70 nop & $36.67 \mathrm{~km}$ & 22.73 & 22.00 & $2722.10 \mathrm{op}$ & $2673.56 \mathrm{klm}$ & 44.37 & $43.23 \mathrm{~g}$ \\
\hline & & $75 \%$ inorg $+25 \%$ org. & 325.36Lmn & 315.54Lmn & $38.30 \mathrm{~m}-\mathrm{p}$ & $37.10 \mathrm{~km}$ & 22.43 & 21.76 & 2766.80 nop & $2683.00 \mathrm{klm}$ & 44.41 & $43.12 \mathrm{~g}$ \\
\hline & & $75 \%$ org. $+25 \%$ inorg. & $322.25 \mathrm{mn}$ & $312.61 \mathrm{mn}$ & $37.93 \mathrm{~m}-\mathrm{p}$ & $36.80 \mathrm{~km}$ & 21.06 & 20.43 & 2740.18 nop & $2657.90 \mathrm{k}-\mathrm{n}$ & 43.27 & $42.07 \mathrm{~h}$ \\
\hline & & $50 \%$ org. $+50 \%$ inorg. & $324.80 \mathrm{Lmn}$ & $315.12 \mathrm{mn}$ & $38.03 \mathrm{~m}-\mathrm{p}$ & $36.93 \mathrm{~km}$ & 23.53 & 22.90 & 2762.15 nop & $2679.03 \mathrm{klm}$ & 45.21 & $43.85 \mathrm{def}$ \\
\hline & & $100 \%$ org. & $318.84 \mathrm{mn}$ & $342.61 \mathrm{f}-\mathrm{L}$ & 37.57 nop & $36.23 \mathrm{Lm}$ & 20.46 & 19.93 & $2701.50 \mathrm{op}$ & $2619.50 \mathrm{~L}-\mathrm{O}$ & 43.25 & $42.02 \mathrm{~h}$ \\
\hline & \multirow{5}{*}{ Yeast } & $100 \%$ inorg. & $375.31 \mathrm{efg}$ & $364.01 \mathrm{c}-\mathrm{g}$ & $44.17 \mathrm{e}-\mathrm{h}$ & $42.67 \mathrm{de}$ & 23.70 & 22.93 & $3191.07 \mathrm{fgh}$ & $3095.53 c-f$ & 46.23 & $44.86 \mathrm{~b}$ \\
\hline & & $75 \%$ inorg $+25 \%$ org. & $412.54 \mathrm{ab}$ & $400.16 \mathrm{a}$ & $48.57 \mathrm{ab}$ & $47.00 \mathrm{a}$ & $\frac{23.53}{3.53}$ & 23.16 & $3506.22 \mathrm{ab}$ & $3401.06 \mathrm{ab}$ & 46.09 & $44.75 \mathrm{~b}$ \\
\hline & & $75 \%$ org. $+25 \%$ inorg. & 380.31 cde & $370.82 \mathrm{~b}-\mathrm{f}$ & $45.90 \mathrm{~cd}$ & $44.53 \mathrm{bc}$ & 22.53 & 21.83 & 3220.25 efg & $3123.03 c-f$ & 45.71 & $44.33 \mathrm{~b}-\mathrm{e}$ \\
\hline & & $\begin{array}{l}50 \% \text { org. }+50 \% \text { inorg. } \\
100 \% \text { orr. }\end{array}$ & $\begin{array}{l}392.63 \mathrm{c} \\
340.05 \mathrm{k}\end{array}$ & $\begin{array}{l}380.85 \mathrm{abc} \\
329.94 \mathrm{i}-\mathrm{n}\end{array}$ & $\begin{array}{l}46.23 \mathrm{c} \\
40.40 \mathrm{k} \mid\end{array}$ & $\begin{array}{l}44.87 \mathrm{~b} \\
39.20 \mathrm{ghi}\end{array}$ & $\begin{array}{l}23.83 \\
2240\end{array}$ & $\frac{23.16}{21.70}$ & $\begin{array}{r}3336.35 \mathrm{~cd} \\
280.15 \mathrm{i}-\mathrm{m}\end{array}$ & $\begin{array}{l}3236.26 \text { a-d } \\
280316 \mathrm{~h}-\mathrm{n}\end{array}$ & $\begin{array}{l}46.91 \\
4.16\end{array}$ & $\begin{array}{l}45.51 \mathrm{a} \\
4382 \mathrm{ef}\end{array}$ \\
\hline & & $\begin{array}{l}100 \% \text { org. } \\
100 \% \text { inora }\end{array}$ & $340.05 \mathrm{jk}$ & $\frac{329.94 i-n}{352301}$ & $\frac{40.40 \mathrm{jk}}{4303 \mathrm{ghi}}$ & $39.20 \mathrm{ghi}$ & $\frac{22.40}{23.73}$ & $\frac{21.70}{2206}$ & $2890.15 j-m$ & 2803.16 h-n & $\begin{array}{l}45.16 \\
46.21 \\
\end{array}$ & $43.82 \mathrm{ef}$ \\
\hline & \multirow{5}{*}{ Garlic } & $\begin{array}{l}100 \% \text { inorg. } \\
75 \% \text { inorg+25\% orq }\end{array}$ & $\begin{array}{l}364.33 \mathrm{gh} \\
392.32 \mathrm{c}\end{array}$ & $\begin{array}{l}353.30 c^{-1} \\
380.51 \text {-d }\end{array}$ & $\begin{array}{l}43.03 \mathrm{ghi} \\
46.17 \mathrm{c}\end{array}$ & $\begin{array}{l}44.83 \mathrm{~b} \\
44.87 \mathrm{~b}\end{array}$ & $\frac{23.73}{24.30}$ & $\begin{array}{l}22.96 \\
2353\end{array}$ & $\begin{array}{l}3141.27 \mathrm{tgh} \\
334712 \mathrm{~cd}\end{array}$ & $3047.17 \mathrm{~d}-\mathrm{h}$ & $\begin{array}{l}46.21 \\
45.92\end{array}$ & $\begin{array}{l}44.83 \mathrm{~b} \\
44.52 \mathrm{bc}\end{array}$ \\
\hline & & $\begin{array}{l}75 \% \text { in org }+25 \% \text { org. } \\
7 \text { ingrg. }\end{array}$ & $\begin{array}{l}392.32 \mathrm{C} \\
371.01 \mathrm{efg}\end{array}$ & $359.84 \mathrm{c}-\mathrm{a}$ & $46.1 / \mathrm{C}$ & $42.03 \mathrm{def}$ & $\frac{24.30}{23.46}$ & 22.76 & $\begin{array}{l}334.12 \mathrm{ca} \\
3141.16 \mathrm{fgh}\end{array}$ & $3046.40 \mathrm{a}-\mathrm{a}$ & 45.74 & $\begin{array}{l}44.52 \mathrm{bC} \\
44.42 \mathrm{bcd}\end{array}$ \\
\hline & & $50 \%$ org. $+50 \%$ inorg. & $\frac{420.51 \mathrm{a}}{420.72 \mathrm{a}}$ & $\frac{374.86 \mathrm{a}-\mathrm{d}}{3.82}$ & $49.47 \mathrm{a}$ & $47.80 \mathrm{a}$ & 25.26 & 24.53 & $3574.62 \mathrm{a}$ & $3466.67 \mathrm{a}$ & 47.36 & $45.96 \mathrm{a}$ \\
\hline & & $100 \%$ org & $363.72 \mathrm{gh}$ & $352.82 \mathrm{c}-j$ & $42.83 \mathrm{hi}$ & $41.57 \mathrm{ef}$ & $\frac{10}{0}$ & 14 & $3090.07 \mathrm{hi}$ & $2997.73 \mathrm{~d}-\mathrm{i}$ & 4.40 & 44.06 cde \\
\hline & & & & & & & NS & NS & & & NS & \\
\hline
\end{tabular}


Tartoura, E A. A et al.

Table (7):Effect of plant spacing, foliar application and nitrogen fertilizer sources on chemical constituents of summer squash leaves during 2011 and 2012 summer season.

\begin{tabular}{|c|c|c|c|c|c|c|c|c|c|c|c|c|}
\hline \multirow[t]{2}{*}{ Treatments } & \multicolumn{2}{|c|}{$N(\%)$} & \multicolumn{2}{|c|}{$\mathbf{P}(\%)$} & \multicolumn{2}{|c|}{$\mathrm{K}(\%)$} & \multicolumn{2}{|c|}{$\mathrm{Fe}(\mathrm{ppm})$} & \multicolumn{2}{|c|}{ Mn (ppm) } & \multicolumn{2}{|c|}{$\mathrm{Zn}$ (ppm) } \\
\hline & 2011 & 2012 & 2011 & 2012 & 2011 & 2012 & 2011 & 2012 & 2011 & 2012 & 2011 & 2012 \\
\hline \multicolumn{13}{|l|}{ Plant spacing (cm) } \\
\hline 30 & $2.147 \mathrm{C}$ & $2.124 \mathrm{c}$ & $0.354 \mathrm{C}$ & $0.345 \mathrm{c}$ & $3.319 \mathrm{C}$ & $3.318 \mathrm{c}$ & $350.51 \mathrm{c}$ & $340.26 \mathrm{c}$ & $152.22 \mathrm{c}$ & $147.22 \mathrm{C}$ & $51.22 \mathrm{c}$ & $49.51 \mathrm{c}$ \\
\hline 45 & $2.223 \mathrm{~b}$ & $2.205 b$ & $0.375 \mathrm{~b}$ & $0.365 \mathrm{~b}$ & $3.375 b$ & $3.276 \mathrm{~b}$ & $378.04 \mathrm{~b}$ & $366.47 \mathrm{~b}$ & $169.55 \mathrm{~b}$ & $164.46 \mathrm{~b}$ & $58.86 \mathrm{~b}$ & $57.62 \mathrm{~b}$ \\
\hline 60 & $2.243 \mathrm{a}$ & $2.225 \mathrm{a}$ & $0.421 \mathrm{a}$ & $0.409 \mathrm{a}$ & $3.422 \mathrm{a}$ & $3.319 \mathrm{a}$ & $417.24 \mathrm{a}$ & $405.17 \mathrm{a}$ & $177.68 \mathrm{a}$ & $172.55 \mathrm{a}$ & $72.22 \mathrm{a}$ & $70.88 a$ \\
\hline F. test & ** & ** & ** & ** & ** & ** & ** & ** & ** & ** & ** & ** \\
\hline \multicolumn{13}{|l|}{ Foliar application } \\
\hline Control & $2.184 \mathrm{C}$ & $2.161 \mathrm{c}$ & $0.379 \mathrm{c}$ & $0.369 \mathrm{c}$ & $3.308 \mathrm{a}$ & $3.210 \mathrm{c}$ & $373.08 \mathrm{c}$ & $362.11 \mathrm{c}$ & $159.42 \mathrm{c}$ & $154.57 \mathrm{c}$ & $57.13 \mathrm{c}$ & $55.22 c$ \\
\hline Yeast extract & $2.201 \mathrm{~b}$ & $2.181 \mathrm{~b}$ & $0.384 \mathrm{~b}$ & $0.374 \mathrm{~b}$ & $3.358 \mathrm{~b}$ & $3.256 \mathrm{~b}$ & $382.20 \mathrm{~b}$ & $371.02 \mathrm{~b}$ & $166.43 \mathrm{~b}$ & $161.37 \mathrm{~b}$ & $60.53 \mathrm{~b}$ & $58.73 \mathrm{~b}$ \\
\hline Garlic extract & $2.228 \mathrm{a}$ & $2.212 \mathrm{a}$ & $0.387 \mathrm{a}$ & $0.376 \mathrm{a}$ & $3.448 \mathrm{a}$ & $3.347 \mathrm{a}$ & $390.51 \mathrm{a}$ & $378.77 \mathrm{a}$ & $173.62 \mathrm{a}$ & $168.28 \mathrm{a}$ & $64.65 \mathrm{a}$ & $63.46 a$ \\
\hline F. test & * & *夫 & ** & ** & ** & ** & ** & ** & ** & ** & ** & ** \\
\hline \multicolumn{13}{|l|}{$\mathbf{N}$ fertilizer sources } \\
\hline $100 \%$ inorganic & $2.202 \mathrm{c}$ & $2.187 \mathrm{~b}$ & $0.383 \mathrm{c}$ & $0.373 \mathrm{c}$ & $3.374 \mathrm{c}$ & $3.270 \mathrm{c}$ & $381.85 \mathrm{c}$ & $370.11 \mathrm{c}$ & $166.52 \mathrm{c}$ & $161.37 \mathrm{c}$ & $60.62 \mathrm{~b}$ & $58.26 \mathrm{c}$ \\
\hline $75 \%$ inorganic $+25 \%$ organic & $2.223 \mathrm{~b}$ & $2.198 \mathrm{~b}$ & $0.385 b$ & $0.375 b$ & $3.388 \mathrm{~b}$ & $3.292 b$ & $384.44 \mathrm{~b}$ & $372.48 \mathrm{~b}$ & $168.07 \mathrm{~b}$ & $163.07 \mathrm{~b}$ & $62.44 \mathrm{a}$ & $60.48 b$ \\
\hline $75 \%$ organic $+25 \%$ inorganic & $2.186 \mathrm{~d}$ & $2.165 \mathrm{c}$ & $0.381 d$ & $0.371 \mathrm{~d}$ & $3.353 d$ & $3.250 \mathrm{~d}$ & $379.74 \mathrm{~d}$ & $368.59 \mathrm{~d}$ & $165.01 \mathrm{~d}$ & $159.74 \mathrm{~d}$ & $59.43 \mathrm{bc}$ & $57.92 c$ \\
\hline $50 \%$ organic $+50 \%$ inorganic & $2.241 \mathrm{a}$ & $2.218 \mathrm{a}$ & $0.388 \mathrm{a}$ & $0.377 \mathrm{a}$ & $3.404 \mathrm{a}$ & $3.307 \mathrm{a}$ & $385.55 \mathrm{a}$ & $375.07 \mathrm{a}$ & $170.11 \mathrm{a}$ & $164.81 \mathrm{a}$ & $62.77 \mathrm{a}$ & $62.18 a$ \\
\hline $100 \%$ organic & $2.170 \mathrm{e}$ & $2.154 \mathrm{c}$ & $0.379 \mathrm{e}$ & $0.369 \mathrm{e}$ & $3.339 \mathrm{e}$ & $3.236 \mathrm{e}$ & $378.07 \mathrm{e}$ & $366.92 \mathrm{e}$ & $162.85 \mathrm{e}$ & $158.17 \mathrm{e}$ & $58.55 \mathrm{c}$ & $56.85 \mathrm{~d}$ \\
\hline F. test & ** & ** & ** & ** & ** & ** & ** & ** & ** & ** & ** & ** \\
\hline
\end{tabular}


Table( 8): Effects of interactions between each two of plant spacing, foliar application and nitrogen fertilizer sources on chemical constituents of summer squash leaves during 2011 and 2012 seasons.

\begin{tabular}{|c|c|c|c|c|c|c|c|c|c|c|c|c|c|}
\hline & Treatment & $\mathbf{N}$ & (\%) & $\mathbf{P}$ & \%) & K & \%) & $\mathrm{Fe} / \mathrm{F}$ & ppm) & $\operatorname{Mn}($ & ppm) & Zn & pm) \\
\hline Pla & $\begin{array}{l}\text { it spacing x Foliar } \\
\text { application }\end{array}$ & 2011 & 2012 & 2011 & 2012 & 2011 & 2012 & 2011 & 2012 & 2011 & 2012 & 2011 & 2012 \\
\hline & Control & $2.124 \mathrm{f}$ & $2.093 \mathrm{~g}$ & $0.351 \mathrm{i}$ & $0.341 \mathrm{~g}$ & $3.218 i$ & $3.122 \mathrm{~g}$ & 342.73 & $332.86 i$ & $145.06 \mathrm{~h}$ & $140.61 \mathrm{~h}$ & $48.11 \mathrm{~h}$ & $46.66 i$ \\
\hline 30 & Yeast & $2.146 \mathrm{e}$ & & $0.356 \mathrm{~h}$ & & $3.317 \mathrm{~h}$ & $3.2197^{7}$ & $349.93 \mathrm{~h}$ & & & $146.86 \mathrm{~g}$ & $51.42 \mathrm{~g}$ & $49.53 \mathrm{~h}$ \\
\hline & $\begin{array}{l}\text { Garlic } \\
\text { Control }\end{array}$ & $\begin{array}{l}2.173 \mathrm{~d} \\
2.206 \mathrm{c}\end{array}$ & $\begin{array}{l}2.152 \mathrm{e} \\
2.188 \mathrm{~d}\end{array}$ & $\begin{array}{l}0.357 \mathrm{~g} \\
0.368 \mathrm{f}\end{array}$ & $\begin{array}{l}0.347 \mathrm{f} \\
0.358 \mathrm{e}\end{array}$ & $\begin{array}{l}3.421 \mathrm{c} \\
3.332 \mathrm{~g}\end{array}$ & $\begin{array}{l}3.312 \mathrm{c} \\
3.236 \mathrm{ef}\end{array}$ & $\begin{array}{l}358.86 d \\
369.13 t\end{array}$ & $\begin{array}{l}348.11 \mathrm{~g} \\
358.06 \mathrm{f}\end{array}$ & $\begin{array}{l}\frac{159.33 \mathrm{f}}{159.94 \mathrm{f}} \\
\end{array}$ & $\begin{array}{l}154.21 \mathrm{f} \\
15493 \mathrm{e}\end{array}$ & $\begin{array}{l}54.26 f \\
56.64 \mathrm{e}\end{array}$ & $\begin{array}{l}52.33 \mathrm{~g} \\
54.73 \mathrm{~g}\end{array}$ \\
\hline 45 & Yeast & $2.224 \mathrm{~b}$ & $2.204 \mathrm{C}$ & $0.371 \mathrm{e}$ & $0.366 \mathrm{~d}$ & 3.3587 & $3.252 \mathrm{e}$ & $378.26 \mathrm{e}$ & & & & $60.11 \mathrm{~d}$ & $57.72 \mathrm{e}$ \\
\hline & Garlic & $2.237 \mathrm{~b}$ & $2.221 \mathrm{~b}$ & $0.382 \mathrm{~d}$ & $0.371 \mathrm{C}$ & $3.435 \mathrm{~b}$ & $3.340 \mathrm{~b}$ & $386.73 \mathrm{~d}$ & & $178.67 \mathrm{~b}$ & $173.22 \mathrm{~b}$ & $59.93 \mathrm{~d}$ & $60.41 \mathrm{~d}$ \\
\hline & Control & $2.224 \mathrm{~b}$ & $2.202 \mathrm{co}$ & $0.418 \mathrm{C}$ & $0.407 \mathrm{~b}$ & $3.376 \mathrm{e}$ & $3.272 \mathrm{~d}$ & $407.41 \mathrm{c}$ & $395.41 \mathrm{c}$ & $173.26 \mathrm{~d}$ & $168.21 \mathrm{~d}$ & $66.74 \mathrm{C}$ & $64.26 \mathrm{c}$ \\
\hline 60 & Yeast & $2.232 \mathrm{~b}$ & $2.212 \mathrm{bc}$ & $0.421 \mathrm{~b}$ & $0.409 a b$ & $3.401 \mathrm{~d}$ & $3.296 \mathrm{C}$ & $418.43 \mathrm{~b}$ & $406.33 \mathrm{~b}$ & $176.94 \mathrm{C}$ & $172.11 \mathrm{c}$ & $70.21 \mathrm{~b}$ & $68.93 \mathrm{~b}$ \\
\hline & Garlic & $2.274 \mathrm{a}$ & $2.263 \mathrm{a}$ & $0.424 \mathrm{a}$ & $0.411 \mathrm{a}$ & $3.492 \mathrm{a}$ & $3.390 \mathrm{a}$ & $425.92 \mathrm{a}$ & $413.82 \mathrm{a}$ & $182.86 \mathrm{a}$ & $177.46 \mathrm{a}$ & $79.73 \mathrm{a}$ & $77.65 \mathrm{a}$ \\
\hline & F. test. & & & & & & & & & & & & \\
\hline Plant spa & ing $x \quad N$ fertilizer source & & & & & & & & & & & & \\
\hline & $75 \%$ inorg $+25 \%$ org. & $\frac{2.134 \mathrm{~g}}{2.161 \mathrm{f}}$ & \begin{tabular}{|l}
$2.119 \mathrm{~h}$ \\
$2.117 \mathrm{~h}$
\end{tabular} & $\begin{array}{l}0.354 \\
0.356\end{array}$ & $\frac{0.344 \mathrm{~m}}{0.347 \mathrm{~L}}$ & \begin{tabular}{|l}
$3.312 \mathrm{~h}$ \\
$3.339 \mathrm{~g}$
\end{tabular} & $\begin{array}{l}3.213 \\
3.237\end{array}$ & $\frac{351.01 \mathrm{~g}}{352.441}$ & $34182 \mathrm{k}$ & $\frac{152.88}{153.34}$ & $\frac{147.88}{148.67}$ & \begin{tabular}{|l}
$50.56 \mathrm{~h}$ \\
$53.01 \mathrm{~g}$ \\
\end{tabular} & $\frac{48.88}{51.11}$ \\
\hline 30 & $75 \%$ org. $+25 \%$ & $2.134 \mathrm{~g}$ & $2.117 \mathrm{~h}$ & 0.353 & $0.343 \mathrm{mn}$ & $3.308 \mathrm{~h}$ & 3.204 & $348.32 \mathrm{~K}$ & & & & & 47.42 \\
\hline & $50 \%$ org. $+50 \%$ inorg. & $2.178 \mathrm{e}$ & $2.151 \mathrm{~g}$ & 0.359 & $0.349 \mathrm{k}$ & $3.351 \mathrm{f}$ & 3.248 & 353.54 & $344.11 j$ & 155.56 & $150.44 i$ & $54.22 \mathrm{~g}$ & 52.33 \\
\hline & $100 \%$ org. & $2.131 \mathrm{~g}$ & $2.121 \hbar$ & 0.351 & $0.342 n$ & $3.286 i$ & 3.186 & $347.22 \mathrm{k}$ & $337.21 \mathrm{~m}$ & 148.22 & $143.21 \mathrm{~L}$ & $49.23 \hbar$ & 47.77 \\
\hline & $100 \%$ inorg. & $2.222 \mathrm{~d}$ & $2.207 \mathrm{~d}$ & 0.375 & $0.366 \mathrm{~h}$ & $3.379 \mathrm{e}$ & 3.275 & $378.11 \mathrm{f}$ & $366.72 \mathrm{~g}$ & 169.44 & $164.22 f$ & $59.33 \mathrm{e}$ & 57.12 \\
\hline & $75 \%$ inorg $+25 \%$ org. & $2.243 c$ & $2.228 \mathrm{C}$ & 0.378 & $0.367 \mathrm{~g}$ & $3.388 \mathrm{de}$ & 3.296 & $382.13 \mathrm{e}$ & & 171.12 & $165.66 \mathrm{e}$ & $60.56 \mathrm{e}$ & 58.55 \\
\hline 45 & $75 \%$ org. $+25 \%$ inorg. & $2.209 \mathrm{~d}$ & $2.191 \mathrm{e}$ & 0.372 & $0.363 i$ & $3.357 \mathrm{f}$ & 3.257 & $375.22 \mathrm{~g}$ & 36 & 168.13 & $162.85 \mathrm{~g}$ & $58.89 \mathrm{ef}$ & 56.67 \\
\hline & $50 \%$ org. $+50 \%$ inorg. & $2.251 \mathrm{bc}$ & $2.229 \mathrm{c}$ & $0.37 \overline{9}$ & $0.369 f$ & $3.403 \mathrm{c}$ & 3.310 & $381.67 \mathrm{e}$ & 37 & \begin{tabular}{|l|}
173.22 \\
\end{tabular} & $168.11 \mathrm{~d}$ & $58.56 \mathrm{ef}$ & 60.66 \\
\hline & $100 \%$ org. & $2.189 \mathrm{e}$ & $2.169 \mathrm{f}$ & 0.371 & $0.361 j$ & $3.349 \mathrm{f}$ & 3.243 & $373.22 \mathrm{~h}$ & 36 & 86 & $42 \mathrm{~h}$ & 57. & 55.11 \\
\hline & $100 \%$ inorg. & $2.252 \mathrm{bc}$ & $2.236 \mathrm{C}$ & 0.421 & $0.409 \mathrm{c}$ & $3.431 \mathrm{~b}$ & 3.322 & 416 & & 177.22 & $11 \mathrm{~b}$ & 72. & 68.76 \\
\hline & $75 \%$ inorg $+25 \%$ org. & $2.263 \mathrm{~b}$ & $2.252 \mathrm{~b}$ & 0.423 & 0.4 & $3.439 \mathrm{~b}$ & 3.342 & $418.78 \mathrm{~b}$ & 406 & 179.76 & & $\mathrm{ab}$ & 71.77 \\
\hline 60 & $75 \%$ org. $+25 \%$ inorg. & $2.216 \mathrm{~d}$ & $2.189 \mathrm{e}$ & 0.419 & $0.408 \mathrm{~d}$ & $3.397 \mathrm{~cd}$ & 3.291 & $415.67 \mathrm{c}$ & $403.15 \mathrm{~cd}$ & 175.77 & $170.45 \mathrm{c}$ & $70.33 \mathrm{~cd}$ & 69.68 \\
\hline & $50 \%$ ord & & & & $0.414 \mathrm{a}$ & $3.461 \mathrm{a}$ & & $421.44 \mathrm{a}$ & $410.32 \mathrm{a}$ & & & 75. & 73.55 \\
\hline & 1 & 2.1 & & 0.416 & $0.404 \mathrm{e}$ & $3.384 \mathrm{e}$ & 3.280 & $413.79 \mathrm{~d}$ & $402.16 \mathrm{~d}$ & 174.44 & $169.55 \mathrm{c}$ & $69.44 \mathrm{~d}$ & 67.66 \\
\hline & F.te & & & NS & & & NS & & & NS & & & NS \\
\hline . & cation $x \mathrm{~N}$ fertilizer sc & & & & & & & & & & & & \\
\hline & $100 \%$ inorg. & 2.184 & $2.157 \mathrm{~g}$ & 0.379 & & 3.3 & 3.21 & 37 & & 159 & & & \\
\hline & $75 \%$ inorg $+25 \%$ org. & & 2.1707 & 0.3 & & & & & & & & & \\
\hline Control & $75 \%$ org. $+25 \%$ inorg. & 2.171 & $2.146 \mathrm{~g}$ & 0.377 & & & 3.186 & & & 157.78 & $1 . / 7$ & $56.11 \mathrm{~g}$ & 54 \\
\hline & $50 \%$ org. $+50 \%$ inorg. & 2.213 & $2.189 \mathrm{e}$ & 0.382 & $0.373 \mathrm{e}$ & 3.3 & 3.241 & 37 & & 163 & 158.12 & $60.15 \mathrm{de}$ & $58.33 \mathrm{~g}$ \\
\hline & $100 \%$ org. & 2.154 & $2.144 \mathrm{~g}$ & 0.375 & 0.3 & 3.289 & 3.183 & & & 155.76 & 150.78 & $55.44 \mathrm{~g}$ & 53.89 \\
\hline & $100 \%$ inorg. & 2.206 & $2.200 \mathrm{de}$ & 0.384 & $0.373 \mathrm{e}$ & $3.361 \mathrm{~g}$ & 3.257 & 382.02 & 369.88 & 166.44 & 161.33 & $60.11 \mathrm{~d}$ & $57.88 \mathrm{gh}$ \\
\hline & $75 \%$ inorg $+25 \%$ & 2.215 & $2.194 \mathrm{de}$ & 0.387 & $0.376 \mathrm{c}$ & 3.3837 & 3.276 & 384.88 & 372.76 & 167.65 & 162.55 & $62.21 \mathrm{c}$ & \\
\hline Yeast & $75 \%$ org & 2.174 & $2.151 \mathrm{~g}$ & 0.383 & 0.3 & $3.337 \mathrm{~h}$ & 3.234 & 379 & 368.84 & 165.33 & & $58.44 \mathrm{de}$ & 57.46 \\
\hline & $50 \%$ org. $+50 \%$ inorg. & 2.243 & $2.219 \mathrm{c}$ & 0.391 & 0.3 & $3.396 \mathrm{e}$ & 3.295 & 386 & 11 & 170.34 & 21 & 63.6 & $61.44 \mathrm{de}$ \\
\hline & $100 \%$ org. & 2.164 & $2.144 \mathrm{~g}$ & 0.382 & & & 3.2 & 378.22 & 36 & $16 \%$ & .09 & & 56.6 \\
\hline & $100 \%$ inorg. & 2.217 & $2.204 \mathrm{~d}$ & 0.387 & & & 3.342 & 390.05 & 44 & & .45 & 65.5 & $63.33 \mathrm{C}$ \\
\hline & $75 \%$ inorg $+25 \%$ org. & 2.251 & $2.232 \mathrm{~b}$ & 0389 & & 3.4 & 3. & 393 & 38 & 17 & & 67. & 65. \\
\hline Garlic & $75 \%$ org. $+25 \%$ inorg. & 2.213 & $2.200 \mathrm{de}$ & 0.385 & & 3.4 & 3. & & & 17 & & & $62.14 \mathrm{~cd}$ \\
\hline & $50 \%$ org. $+50 \%$ inorg. & 2.267 & $2.249 \mathrm{a}$ & 0.392 & $0.381 \mathrm{a}$ & $3.478 \mathrm{a}$ & 3.384 & 393.88 & & 176.55 & 171.11 & $64.67 \mathrm{~b}$ & $66.78 \mathrm{a}$ \\
\hline & $100 \%$ org. & 2.193 & $2.176 \mathrm{f}$ & 0.383 & $0.372 \mathrm{f}$ & $3.412 \mathrm{~d}$ & 3.310 & 386.86 & 374.55 & 170.46 & 165.58 & $62.16 \mathrm{c}$ & $60.01 \mathrm{f}$ \\
\hline & F.te & & & & & & & & & & & & \\
\hline
\end{tabular}


Table 9: Effect of interactions among plant spacing, foliar application and nitrogen fertilizer sources on chemical constituents of summer squash leaves during 2011 and 2012 seasons.

\begin{tabular}{|c|c|c|c|c|c|c|c|c|c|c|c|c|c|c|}
\hline \multirow{2}{*}{\begin{tabular}{|c|} 
Plant \\
spacing
\end{tabular}} & \multicolumn{2}{|c|}{ Treatment } & \multicolumn{2}{|c|}{$\mathbf{N}(\%)$} & \multicolumn{2}{|c|}{$P(\%)$} & \multicolumn{2}{|c|}{$K(\%)$} & \multicolumn{2}{|c|}{$\mathrm{Fe}(\mathrm{ppm})$} & \multicolumn{2}{|c|}{ Mn (ppm) } & \multicolumn{2}{|c|}{ Zn (ppm) } \\
\hline & $\begin{array}{l}\text { Foliar } \\
\text { oplication }\end{array}$ & $\begin{array}{l}\text { N fertilizers } \\
\text { sources }\end{array}$ & 2011 & 2012 & 2011 & 2012 & 2011 & 2012 & 2011 & 2012 & 2011 & 2012 & 2011 & 2012 \\
\hline \multirow{15}{*}{30} & & $100 \%$ inorg. & $3.453 \mathrm{rs}$ & $3.353 \mathrm{pq}$ & 0.435 & $0.421 \mathrm{v}$ & $1.303 z$ & $1.265 \mathrm{z}$ & $341.66 \mathrm{x}$ & $332.01 \mathrm{tu}$ & 145.67 & 141.01 & $46.67 \mathrm{z}$ & $45.67 \mathrm{yz}$ \\
\hline & $\stackrel{c}{s}$ & o inorg $+25 \%$ org. & 3.463 grs & $3.363 p$ & 0.439 & $0.426 \mathrm{stu}$ & $1.303 \mathrm{z}$ & $1.265 \mathrm{z}$ & $343.67 \mathrm{wx}$ & $333.72 \mathrm{t}$ & 146.33 & 143.05 & & $48.11 \mathrm{wxy}$ \\
\hline & हू- & norg. & $3.436 \mathrm{st}$ & $3.326 \mathrm{qr}$ & 0.432 & $0.418 \mathrm{w}$ & $1.295 \mathrm{z}$ & $1.257 \mathrm{z}$ & $341.33 x$ & $331.32 \mathrm{u}$ & 143.34 & 139.11 & $45.33 z$ & $44.01 \mathrm{z}$ \\
\hline & & $50 \%$ org. $+50 \%$ inorg. & $3.516 \mathrm{op}$ & 3.420 no & 0.443 & $0.431 \mathrm{po}$ & $1.306 \mathrm{z}$ & $1.265 \mathrm{z}$ & $345.64 \mathrm{vw}$ & $336.11 \mathrm{~s}$ & 149.12 & 144.16 & $51.12 \mathrm{w}-\mathrm{z}$ & $49.33 u-x$ \\
\hline & & $100 \%$ org. & $3.416 j$ & $3.317 \mathrm{r}$ & 0.431 & $0.418 \mathrm{w}$ & $1.292 \mathrm{q}$ & $1.255 \mathrm{z}$ & $341.32 x$ & $331.32 \mathrm{u}$ & 141.15 & 136.12 & $47.33 \mathrm{z}$ & $46.34 y$ \\
\hline & & $100 \%$ inorg. & $3.513 p$ & 3.4070 & 0.438 & $0.425 \mathrm{u}$ & $1.308 \mathrm{z}$ & $1.268 \mathrm{y}$ & $352.13 \mathrm{u}$ & $339.31 \mathrm{qr}$ & 152.68 & 147.33 & $51.15 w-z$ & $49.12 \mathrm{wwx}$ \\
\hline & $\overline{9}$ & $75 \%$ inorg $+25 \%$ org & 3.516 op & $3.417 \mathrm{no}$ & 0.445 & $0.431 \mathrm{pq}$ & $1.312 \mathrm{z}$ & $1.273 x$ & $351.65 \mathrm{u}$ & $341.12 \mathrm{q}$ & 152.66 & 147.32 & $53.33 \mathrm{~s}-\mathrm{x}$ & $51.33 \mathrm{~s}-\mathrm{v}$ \\
\hline & $\pi$ & $75 \%$ org. $+25 \%$ inorg & $3.486 \mathrm{pq}$ & $3.388 \mathrm{op}$ & 0.437 & $0.424 \mathrm{u}$ & $1.306 z$ & $1.268 \mathrm{x}$ & $347.01 \mathrm{v}$ & $338.72 \mathrm{r}$ & 152.34 & 146.15 & $49.13 \mathrm{yz}$ & $47.35 x y$ \\
\hline & & $50 \%$ org. $+50 \%$ inorg. & $3.553 \mathrm{mn}$ & $3.443 \mathrm{mn}$ & 0.446 & 0.433 nop & $1.313 \mathrm{z}$ & $1.272 x$ & 353.64 tu & $344.73 \mathrm{p}$ & 156.11 & 151.17 & $55.11 \mathrm{r}-\mathrm{v}$ & $53.11 \mathrm{grs}$ \\
\hline & & $100 \%$ org. & $3.476 \mathrm{gr}$ & $3.367 \mathrm{p}$ & 0.435 & $0.422 \mathrm{~V}$ & $1.306 \mathrm{z}$ & $1.267 \mathrm{v}-\mathrm{z}$ & $345.33 \mathrm{vw}$ & $336.02 \mathrm{~s}$ & 147.68 & 142.68 & $48.67 \mathrm{yz}$ & $47.01 \mathrm{xy}$ \\
\hline & & $100 \%$ inorg. & $3.563 \mathrm{lmn}$ & $3.463 \mathrm{klm}$ & 0.344 & $0.431 \mathrm{pq}$ & $1.320 \mathrm{y}$ & $1.280 \mathrm{~V}$ & $359.33 \mathrm{r}$ & 347.750 & 160.33 & 155.33 & $54.16 \mathrm{r}-\mathrm{w}$ & $52.13 \mathrm{rst}$ \\
\hline & $\underline{=}$ & $75 \%$ inorg $+25 \%$ org. & $3.633 \mathrm{~d}-\mathrm{g}$ & $3.531 \mathrm{~b}-\mathrm{g}$ & 0.446 & $0.432 \mathrm{opq}$ & $1.324 x$ & $1.224 \mathrm{u}$ & $362.11 \mathrm{q}$ & $350.74 n$ & 161.01 & & & $1.17 \mathrm{pqr}$ \\
\hline & 言 & $75 \%$ org. $+25 \%$ inorg. & 3.546 no & $3.447 \mathrm{Lmn}$ & 0.441 & $0.427 \mathrm{st}$ & $1.318 \mathrm{z}$ & $1.280 \mathrm{~V}$ & $356.68 \mathrm{~s}$ & $346.11 \mathrm{op}$ & 157.67 & 102.00 & $53.23 t-x$ & $51.75 \mathrm{~s}-\mathrm{v}$ \\
\hline & & $50 \%$ org. $+50 \%$ inorg. & $3.573 j-n$ & $3.467 \mathrm{klm}$ & 0.447 & 0.433 nop & $1.328 \mathrm{w}$ & $1.287 \mathrm{t}$ & $361.33 q$ & $351.32 n$ & 161.67 & 156.34 & $56.67 \mathrm{qt}$ & $54.67 \mathrm{opq}$ \\
\hline & & $100 \%$ org. & $3.553 \mathrm{mn}$ & $3.453 \mathrm{Lmn}$ & 0.441 & $0.427 \mathrm{~s}$ & $1.315 \mathrm{z}$ & $1.274 \mathrm{w}$ & $355.12 \mathrm{st}$ & $344.31 \mathrm{p}$ & 156.14 & 151.14 & $51.65 \mathrm{vy}$ & $50.14 t-w$ \\
\hline \multirow{16}{*}{45} & & $100 \%$ inorg. & $3.570 \mathrm{k}-\mathrm{n}$ & $3.467 \mathrm{klm}$ & 0.442 & $0.426 \mathrm{~s}-\mathrm{t}$ & $1.336 \mathrm{t}$ & $1.296 \mathrm{q}$ & 371.670 & $360.15 \mathrm{~L}$ & 159.67 & & $56.11 q-u$ & $54.16 \mathrm{pqr}$ \\
\hline & $\stackrel{2}{=}$ & $75 \%$ inorg $+25 \%$ org. & $3.603 \mathrm{~g}-\mathrm{k}$ & $3.508 \mathrm{~d}-\mathrm{j}$ & 0.446 & $0.432 \mathrm{pq}$ & $1.336 \mathrm{t}$ & $1.296 \mathrm{q}$ & 372.640 & $360.31 \mathrm{~L}$ & 161.68 & & $57.02 p-s$ & $\mathrm{opq}$ \\
\hline & & $75 \%$ org.+25\% inorg. & $3.550 \mathrm{mn}$ & $3.451 \mathrm{Lmn}$ & 0.442 & $0.427 \mathrm{rs}$ & $1.334 \mathrm{u}$ & $1.294 \mathrm{r}$ & $365.12 \mathrm{~b}$ & $354.72 \mathrm{~m}$ & 158.33 & 153.12 & $56.21 \mathrm{q}-\mathrm{u}$ & $54.31 \mathrm{pqr}$ \\
\hline & & $50 \%$ org. $+50 \%$ inorg. & $3.626 \mathrm{~d}-\mathrm{g}$ & $3.513 \mathrm{~d}-\mathrm{i}$ & 0.447 & 0.4319 & $1.340 \mathrm{~s}$ & $1.299 \mathrm{p}$ & 371.640 & $361.13 \mathrm{~L}$ & 164.32 & 159.64 & $60.67 \mathrm{~L}-\mathrm{p}$ & $59.11 \mathrm{Lm}$ \\
\hline & & $100 \%$ org. & $3.570 \mathrm{k}-\mathrm{n}$ & $3.463 \mathrm{klm}$ & 0.439 & 0.425 tu & $1.331 \mathrm{v}$ & $1.291 \mathrm{~s}$ & $364.65 b$ & $354.32 \mathrm{~m}$ & 155.68 & & $53.68 \mathrm{~s}-\mathrm{w}$ & $51.67 \mathrm{r}-\mathrm{u}$ \\
\hline & & $100 \%$ inorg. & $3.620 \mathrm{e}-\mathrm{h}$ & $3.522 \mathrm{~d}-\mathrm{h}$ & 0.446 & $0.432 \mathrm{pq}$ & $1.347 \mathrm{qr}$ & $1.308 \mathrm{n}$ & $376.33 n$ & $365.71 \mathrm{k}$ & 170.11 & 165 & $59.12 n-q$ & 56.33 nop \\
\hline & $\bar{\omega}$ & $75 \%$ inorg $+25 \%$ org. & $3.613 \mathrm{f}-\mathrm{i}$ & $3.497 \mathrm{fk}$ & 0.447 & 0.433 nop & $1.350 \mathrm{p}$ & $1.310 \mathrm{~m}$ & $381.64 \mathrm{Lm}$ & $368.35 \mathrm{j}$ & 171.35 & 166.17 & $61.15 \mathrm{~L}-\mathrm{O}$ & $59.11 \mathrm{Lm}$ \\
\hline & 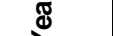 & $5 \%$ inorg. & $3.583 \mathrm{i}-\mathrm{m}$ & $3.507 \mathrm{~d}-\mathrm{j}$ & 0.443 & $0.429 \mathrm{r}$ & $1.347 \mathrm{qr}$ & $1.306 \mathrm{mo}$ & $376.32 n$ & $364.34 \mathrm{k}$ & 169.13 & & & $57.10 \mathrm{mno}$ \\
\hline & & $0 \%$ inorg. & $3.616 \mathrm{f-i}$ & & 0.4 & $0.437 \mathrm{ijk}$ & $1.352 \mathrm{op}$ & $1.312 \mathrm{~m}$ & & & & & & $3 \mathrm{kl}$ \\
\hline & & $100 \%$ org. & $3.570 \mathrm{k}-\mathrm{n}$ & $3.473 \mathrm{j}-\mathrm{m}$ & 0.442 & $0.429 \mathrm{r}$ & $1.346 \mathrm{r}$ & 1.3030 & 373.330 & $362.15 \mathrm{~L}$ & 166.33 & 162.68 & $57.640-r$ & 56.22 nop \\
\hline & & $100 \%$ inorg. & $3.623 \mathrm{~d}-\mathrm{h}$ & $3.497 \mathrm{f}-\mathrm{k}$ & 0.452 & $0.436 \mathrm{klm}$ & 1.3520 & $1.311 \mathrm{~m}$ & $386.15 \mathrm{j}$ & $374.31 \mathrm{i}$ & 178.66 & 173.67 & $63.11 \mathrm{j}-\mathrm{m}$ & $61.01 \mathrm{kl}$ \\
\hline & & $75 \%$ inorg $+25 \%$ org. & $3.646 \mathrm{~b}-\mathrm{f}$ & $3.531 \mathrm{~b}-\mathrm{g}$ & 0.451 & $0.438 \mathrm{i}$ & $1.355 n$ & $1.314 \mathrm{~L}$ & $392.13 \mathrm{~h}$ & $379.14 \mathrm{~h}$ & 180.34 & 174.33 & $63.63 \mathrm{i}-\mathrm{L}$ & $61.67 \mathrm{jk}$ \\
\hline & $\overline{\frac{\pi}{\sigma}}$ & $75 \%$ org. $+25 \%$ inorg. & $3.616 \mathrm{f-i}$ & $3.483 \mathrm{~h}-\mathrm{L}$ & 0.448 & $0.435 \mathrm{klm}$ & $1.352 \mathrm{op}$ & $1.310 \mathrm{~m}$ & $384.33 \mathrm{jk}$ & $373.17 \mathrm{i}$ & 177.02 & & $61.14 \mathrm{~L}-0$ & $59.03 \mathrm{Lm}$ \\
\hline & & $50 \%$ org.+50\% inorg. & $3.626 \mathrm{~d}-\mathrm{g}$ & $3.523 \mathrm{~d}-\mathrm{h}$ & 0.455 & $0.442 \mathrm{gh}$ & $1.357 \mathrm{~m}$ & $1.317 \mathrm{k}$ & $389.65 \mathrm{i}$ & $378.11 \mathrm{~h}$ & & & & $62.67 \mathrm{ijk}$ \\
\hline & & $100 \%$ org. & $3.590 \mathrm{~h}-\mathrm{L}$ & $3.481 \mathrm{i}-\mathrm{m}$ & 0.447 & $0.434 \mathrm{mno}$ & $1.348 \mathrm{q}$ & $1.307 \mathrm{n}$ & 381.6 & $368.25 \mathrm{j}$ & & & $59.67 \mathrm{~m}-\mathrm{q}$ & $57.68 \mathrm{mn}$ \\
\hline & & $100 \%$ inorg & $3.590 \mathrm{~h}-\mathrm{L}$ & $3.471 \mathrm{j}-\mathrm{m}$ & 0.452 & $0.436 \mathrm{jkl}$ & $1.376 j$ & $1.340 \mathrm{gh}$ & $407.34 \mathrm{f}$ & $394.15 f$ & 172.33 & 176.33 & $66.06 \mathrm{~h}-\mathrm{k}$ & $61.12 \mathrm{kl}$ \\
\hline \multirow{15}{*}{60} & & $75 \%$ inorg $+25 \%$ org & $3.606 \mathrm{~g}-\mathrm{j}$ & $3.493 \mathrm{~g}-\mathrm{k}$ & 0.451 & $0.438 \mathrm{ii}$ & $1.379 \mathrm{i}$ & $1.342 \mathrm{~g}$ & $408.65 f$ & $396.22 f$ & 175.67 & & $67.33 \mathrm{ghi}$ & $65.33 \mathrm{jh}$ \\
\hline & & $75 \%$ org. $+25 \%$ inorg. & $3.570 \mathrm{k}-\mathrm{n}$ & $3.463 \mathrm{klm}$ & 0.448 & $0.434 \mathrm{Lmn}$ & $1.374 \mathrm{k}$ & $1.335 \mathrm{i}$ & $407.33 \mathrm{f}$ & $394.71 \mathrm{f}$ & 171.64 & 16 & $66.67 \mathrm{hij}$ & $64.66 \mathrm{jhi}$ \\
\hline & & $50 \%$ org & $\frac{d-h}{}$ & $d-i$ & 0.455 & 0.44 & $1.382 \mathrm{~h}$ & $1.344 f$ & & 401 & & & 68.34 jh & $66.67 \mathrm{fg}$ \\
\hline & & $100 \%$ org. & & & 0.4 & & $1.371 \mathrm{~L}$ & & & & & & $65.31 \mathrm{~h}-\mathrm{k}$ & $63.64 \mathrm{hij}$ \\
\hline & & $100 \%$ inorg. & $6 b-f$ & $3.541 \mathrm{bcd}$ & 0.455 & 0.44 & $1.384 \mathrm{~g}$ & $1.344 \mathrm{f}$ & 417 & 40 & 17 & 171 & $70.33 \mathrm{fg}$ & $68.33 \mathrm{ef}$ \\
\hline & & $75 \%$ inorg & $3.656 \mathrm{bcd}$ & $3.533 \mathrm{~b}-\mathrm{f}$ & 0.457 & $0.443 \mathrm{fgh}$ & $1.386 \mathrm{f}$ & $1.350 \mathrm{e}$ & & & & & $72.35 \mathrm{ef}$ & \\
\hline & & $75 \%$ org. $+25 \%$ inorg. & $3.676 \mathrm{bc}$ & $3.567 \mathrm{~b}$ & 0.454 & $0.441 \mathrm{~h}$ & $1.382 \mathrm{~h}$ & $1.339 \mathrm{~h}$ & $415.65 d$ & $403.71 \mathrm{de}$ & 174.66 & & $66.67 \mathrm{hij}$ & $68.15 f$ \\
\hline & & $50 \%$ org. $+50 \%$ inorg. & $3.623 \mathrm{a}$ & $3.621 \mathrm{a}$ & 0.459 & $0.445 \mathrm{de}$ & $1.392 \mathrm{e}$ & $1.353 \mathrm{~d}$ & $421.36 \mathrm{c}$ & $410.12 \mathrm{C}$ & 181.34 & & $73.33 \mathrm{ef}$ & $71.04 \mathrm{~d}$ \\
\hline & & $100 \%$ org. & $3.636 \mathrm{~d}-\mathrm{g}$ & $3.527 \mathrm{c}-\mathrm{g}$ & 0.451 & \begin{tabular}{|l|l|}
$0.437 \mathrm{ij}$ \\
\end{tabular} & $1.382 \mathrm{~h}$ & $1.340 \mathrm{gh}$ & $416.15 \mathrm{~d}$ & $404.31 \mathrm{~d}$ & 173.15 & 168.33 & $68.34 \mathrm{gh}$ & $67.11 \mathrm{fg}$ \\
\hline & & $100 \%$ inorg. & $3.653 \mathrm{~b}-\mathrm{e}$ & $3.543 \mathrm{bcd}$ & 0.451 & $0.446 \mathrm{~d}$ & $1.400 \mathrm{c}$ & $1.362 \mathrm{~b}$ & $424.64 b$ & $413.32 \mathrm{~b}$ & 182.68 & 177.11 & $79.68 \mathrm{bc}$ & $77.16 \mathrm{c}$ \\
\hline & & $75 \%$ inorg $+25 \%$ org. & $3.680 \mathrm{~b}$ & $3.563 \mathrm{bc}$ & 0.462 & \begin{tabular}{|l|l|}
$0.447 \mathrm{c}$ \\
\end{tabular} & $1.403 \mathrm{~b}$ & $1.360 \mathrm{c}$ & $426.33 \mathrm{~b}$ & $414.34 \mathrm{~b}$ & 184.65 & 179.33 & $81.67 \mathrm{~b}$ & $79.67 \mathrm{~b}$ \\
\hline & 논 & $75 \%$ org. $+25 \%$ inorg. & $3.643 \mathrm{c}-\mathrm{e}$ & $3.537 \mathrm{~b}-\mathrm{e}$ & 0.457 & $0.443 \mathrm{efg}$ & $1.396 \mathrm{~d}$ & $1.355 \mathrm{~d}$ & $424.12 \mathrm{~b}$ & $411.21 \mathrm{c}$ & 181.17 & 175.35 & $77.68 \mathrm{~cd}$ & $76.34 \mathrm{c}$ \\
\hline & (ै) & $50 \%$ org. $+50 \%$ inorg. & $3.743 \mathrm{a}$ & $3.633 \mathrm{a}$ & 0.463 & $0.451 \mathrm{a}$ & $1.407 \mathrm{a}$ & $1.367 \mathrm{a}$ & $430.67 \mathrm{a}$ & $419.35 \mathrm{a}$ & 186.34 & 181.15 & $85.12 \mathrm{a}$ & $83.17 \mathrm{a}$ \\
\hline & & $100 \%$ org. & $3.616 \mathrm{f}-\mathrm{i}$ & $3.501 \mathrm{e}-\mathrm{k}$ & 0.492 & $0.444 \mathrm{def}$ & $1.392 \mathrm{e}$ & $1.351 \mathrm{e}$ & $424.17 \mathrm{~b}$ & $411.12 \mathrm{c}$ & 179.65 & 174.68 & $74.64 \mathrm{de}$ & $72.33 d$ \\
\hline & & test & & & NS & & & & & & NS & & & \\
\hline
\end{tabular}

